\title{
Transcriptomics of single dose and repeated carbon black and ozone inhalation co-exposure highlight progressive pulmonary mitochondrial dysfunction
}

Quincy A. Hathaway ${ }^{1,2,3 \dagger}$, Nairrita Majumder ${ }^{3,4 \dagger}$, William T. Goldsmith ${ }^{3,4}$, Amina Kunovac ${ }^{1,2,3}$, Mark V. Pinti ${ }^{2,5}$, Jack R. Harkema ${ }^{6}$, Vince Castranova ${ }^{3}$, John M. Hollander ${ }^{1,2,3}$ and Salik Hussain ${ }^{2,3,4^{*}}$ (D)

\begin{abstract}
Background: Air pollution is a complex mixture of particles and gases, yet current regulations are based on single toxicant levels failing to consider potential interactive outcomes of co-exposures. We examined transcriptomic changes after inhalation co-exposure to a particulate and a gaseous component of air pollution and hypothesized that co-exposure would induce significantly greater impairments to mitochondrial bioenergetics. A whole-body inhalation exposure to ultrafine carbon black (CB), and ozone $\left(\mathrm{O}_{3}\right)$ was performed, and the impact of single and multiple exposures was studied at relevant deposition levels. C57BL/6 mice were exposed to $\mathrm{CB}\left(10 \mathrm{mg} / \mathrm{m}^{3}\right)$ and/or $\mathrm{O}_{3}(2 \mathrm{ppm})$ for $3 \mathrm{~h}$ (either a single exposure or four independent exposures). RNA was isolated from lungs and mRNA sequencing performed using the Illumina HiSeq. Lung pathology was evaluated by histology and immunohistochemistry. Electron transport chain (ETC) activities, electron flow, hydrogen peroxide production, and ATP content were assessed.
\end{abstract}

Results: Compared to individual exposure groups, co-exposure induced significantly greater neutrophils and protein levels in broncho-alveolar lavage fluid as well as a significant increase in mRNA expression of oxidative stress and inflammation related genes. Similarly, a significant increase in hydrogen peroxide production was observed after coexposure. After single and four exposures, co-exposure revealed a greater number of differentially expressed genes (2251 and 4072, respectively). Of these genes, 1188 (single exposure) and 2061 (four exposures) were uniquely differentially expressed, with 35 mitochondrial ETC mRNA transcripts significantly impacted after four exposures. Both $\mathrm{O}_{3}$ and co-exposure treatment significantly reduced ETC maximal activity for complexes I ( $-39.3 \%$ and $-36.2 \%$, respectively) and IV ( $-55.1 \%$ and $-57.1 \%$, respectively). Only co-exposure reduced ATP Synthase activity $(-35.7 \%)$ and total ATP content (30\%). Further, the ability for ATP Synthase to function is limited by reduced electron flow $(-25 \%)$ and translation of subunits, such as ATP5F1, following co-exposure.

\footnotetext{
${ }^{*}$ Correspondence: salik.hussain@hsc.wvu.edu

${ }^{\dagger}$ Quincy A. Hathaway and Nairrita Majumder have contributed equally to this work

${ }^{4}$ Department of Physiology and Pharmacology, West Virginia University School of Medicine, 64 Medical Center Drive, PO Box 9229, Morgantown WV 26506-9229, USA

Full list of author information is available at the end of the article
} permits use, sharing, adaptation, distribution and reproduction in any medium or format, as long as you give appropriate credit to the original author(s) and the source, provide a link to the Creative Commons licence, and indicate if changes were made. The images or other third party material in this article are included in the article's Creative Commons licence, unless indicated otherwise in a credit line to the material. If material is not included in the article's Creative Commons licence and your intended use is not permitted by statutory regulation or exceeds the permitted use, you will need to obtain permission directly from the copyright holder. To view a copy of this licence, visit http://creativecommons.org/licenses/by/4.0/. The Creative Commons Public Domain Dedication waiver (http://creativeco mmons.org/publicdomain/zero/1.0/) applies to the data made available in this article, unless otherwise stated in a credit line to the data. 
Conclusions: $\mathrm{CB}$ and $\mathrm{O}_{3}$ co-exposure cause unique transcriptomic changes in the lungs that are characterized by functional deficits to mitochondrial bioenergetics. Alterations to ATP Synthase function and mitochondrial electron flow underly a pathological adaptation to lung injury induced by co-exposure.

Keywords: Ozone, Carbon black, Ultrafine/nanoparticle, Inhalation toxicology, Mitochondria, Genomics, Lung, Environmental exposure

\section{Introduction}

According to the World Health Organization, over 4 million deaths annually are attributed to outdoor environmental pollution [1]. Additionally, an increase in air pollution is associated with a tremendous economic burden, a significant increase in disability adjusted life years (DALYs), and an increase in hospitalizations due to exacerbation of pre-existing respiratory and systemic disorders [2-4]. Air pollution is a heterogenous mixture of particulates and gaseous components. Composition of this mixture is highly variable and depends upon a variety of factors including source and atmospheric conditions. These particulate and gaseous air pollution components dynamically shape health outcomes [5]. While air pollution exposures are known to be very heterogenous, most experimental research and current regulations are based on single toxicant exposure. These single toxicant studies fail to account for the potential interactive impacts of the particulate and gaseous components. Recent epidemiological data indicate that gaseous and particulate components interact in shaping the health impacts of air pollution [6]. It is plausible that these interactions are the basis of the observed increases in air pollution associated lung and systemic pathologies despite a significant drop in the mass of air pollution constituents over the past decades [7]. This information is critically needed not only to improve regulatory guidelines but also to enhance the protection of global environmental health.

Ozone $\left(\mathrm{O}_{3}\right)$ is one of the most reactive gaseous components of air pollution and is among six criteria pollutants identified/regulated by the US Environmental Protection Agency (EPA). Ground level $\mathrm{O}_{3}$ is generated by photochemical reactions between the ultraviolet component of sunlight and oxides of nitrogen and volatile organic compounds from vehicular emissions. Both epidemiological and experimental evidence confirm the ability of a short term acute $\mathrm{O}_{3}$ exposure to aggravate pre-existing disorders [8-10]. Global $\mathrm{O}_{3}$ exposure was estimated to be associated with 2,540,000 deaths and a $14 \%$ increase in global $\mathrm{O}_{3}$ levels is anticipated in the next two decades [2, $11,12]$. Ultrafine/nano carbon black $(\mathrm{CB})$ is widely used as a reinforcing agent in rubber, printing, and leather industries [13]. Global consumption of engineered carbon black is forecasted to reach 19.2 million metric tons, valued at $\$ 20.4$ billion, by 2022 [14]. CB is classified as a possible human carcinogen (2B) by the International Agency for Research on Cancer (IARC) [15].

$\mathrm{CB}$ provides a unique opportunity to study the contribution of the carbon core of particulate matter without interferences from any additives. In addition, there is the possibility of adding additional components as CB particles are excellent carriers of environmental toxicants. A limited number of studies previously addressed particle (PM, diesel exhaust particles, $\mathrm{CB}$ ) and $\mathrm{O}_{3}$ exposure in a sequential manner and identified potentials for deleterious cardiovascular outcomes and increased lung injury and irritation [16-19]. A recent study demonstrated increased lung injury and formation of a fluvic acidlike substance after intratracheal administration of $\mathrm{O}_{3}$ reacted $\mathrm{CB}$ particles [20]. To date, only a few $\mathrm{PM}$ and $\mathrm{O}_{3}$ co-exposure studies have been performed, which mainly focused on cardiovascular outcomes and did not address pulmonary inflammatory mechanisms [21-23]. A recent study indicated the potential of ultrafine $\mathrm{PM}$ and $\mathrm{O}_{3}$ coexposure to increase lung injury in spontaneously hypertensive rats [24]. These studies clearly suggest a potential for interactive outcomes after particle and gaseous co-exposures.

The application of broad-scale sequencing and "omics" approaches have been used in studies examining the health effects of air toxicants [25-27]. Specifically, transcriptomics provides a useful tool to determine the immediate adaptation, or maladaptation, after a stimulus. In both newborn [28] and adult [29] mice, $\mathrm{O}_{3}$ exposure is associated with alterations to the pulmonary transcriptome, which contribute to cellular signaling involving cellular proliferation and differentiation. Maternal exposure to $\mathrm{CB}$ has been linked to transcriptomic changes in extrapulmonary organs of progeny, such as the hippocampus [30] and liver [31]. While these studies demonstrate the evident impact of $\mathrm{O}_{3}$ and $\mathrm{CB}$ on mRNA expression, they are unable to model the interaction of these toxicants in vivo to induce potentially new or more exaggerated cellular responses.

The purpose of this study was to use transcriptomics as a tool to identify unique pathways induced by $\mathrm{CB}$ and $\mathrm{O}_{3}$ co-exposure (hypothesis generating) and to further assess the validity of these pathways using functional assessments (hypothesis testing). We explored these responses in a single vs multiple exposure scenario and 
evaluated transcriptomic findings using histological and biochemical methods. We also developed an inhalation co-exposure system with advanced engineering controls and a real-time feedback monitoring system to enable co-exposure inhalation studies that directly model environmental exposure scenarios. A better understanding of the co-exposure-induced unique transcriptional pathways and molecular adaptations in the lungs will aid in development of more realistic and effective public health measures for preventing air pollution-induced pulmonary and systemic pathologies.

\section{Materials and methods}

\section{Exposure system and aerosol characterization}

A whole-body inhalation exposure system was designed to expose up to 36 mice simultaneously to CB aerosols, $\mathrm{O}_{3}$, or a mixture of the two toxicants. A diagram of the system is shown in Fig. 1. Ultrafine CB $(14 \pm 4 \mathrm{~nm}$ primary particle diameter) (Printex $90^{\circledR}$, a gift from Evonik, Frankfurt, Germany), was placed within a modified high-pressure acoustical generator (HPAG, IEStechno, Morgantown, WV). Acoustical energy deagglomerated and aerosolized the $\mathrm{CB}$ material. Compressed air was dried then filtered through HEPA (high efficiency particulate air filter) and charcoal. Clean air was passed through the HPAG and the air-CB aerosol mix was fed into a venturi pump (JS-60 M, Vaccon, Medway MA) that acted as a second stage for particle deagglomeration. A light scattering monitor (DataRAM, pDr-1500, Thermo Environmental Instruments Inc, Franklin, MA) sampled the airstream to estimate the real-time mass concentration of the aerosol. $\mathrm{O}_{3}$ was generated by passing clean air or oxygen through a corona discharge $\mathrm{O}_{3}$ generator (HTU500AC, Ozone Solutions, Hull, IA).

During co-exposures, the $\mathrm{CB}$ aerosol was mixed with the $\mathrm{O}_{3}$ before entering the exposure chamber. A 150-L stainless-steel exposure chamber (Cube 150, IEStechno, Morgantown, WV) with mice individually housed in a 36-mouse cage rack was used for all exposures. $\mathrm{O}_{3}$ levels were monitored during exposures with a calibrated $\mathrm{O}_{3}$ monitor (Model 202, 2B Technologies, Inc., Boulder, CO). Gravimetric mass concentration measurements were conducted over the duration of each exposure. The gravimetric results were used to report results and to continually calibrate the DataRAM. Temperature $\left(20-22{ }^{\circ} \mathrm{C}\right)$, relative humidity (50-70\%) (HMT330, Vaisala, Helsinki,

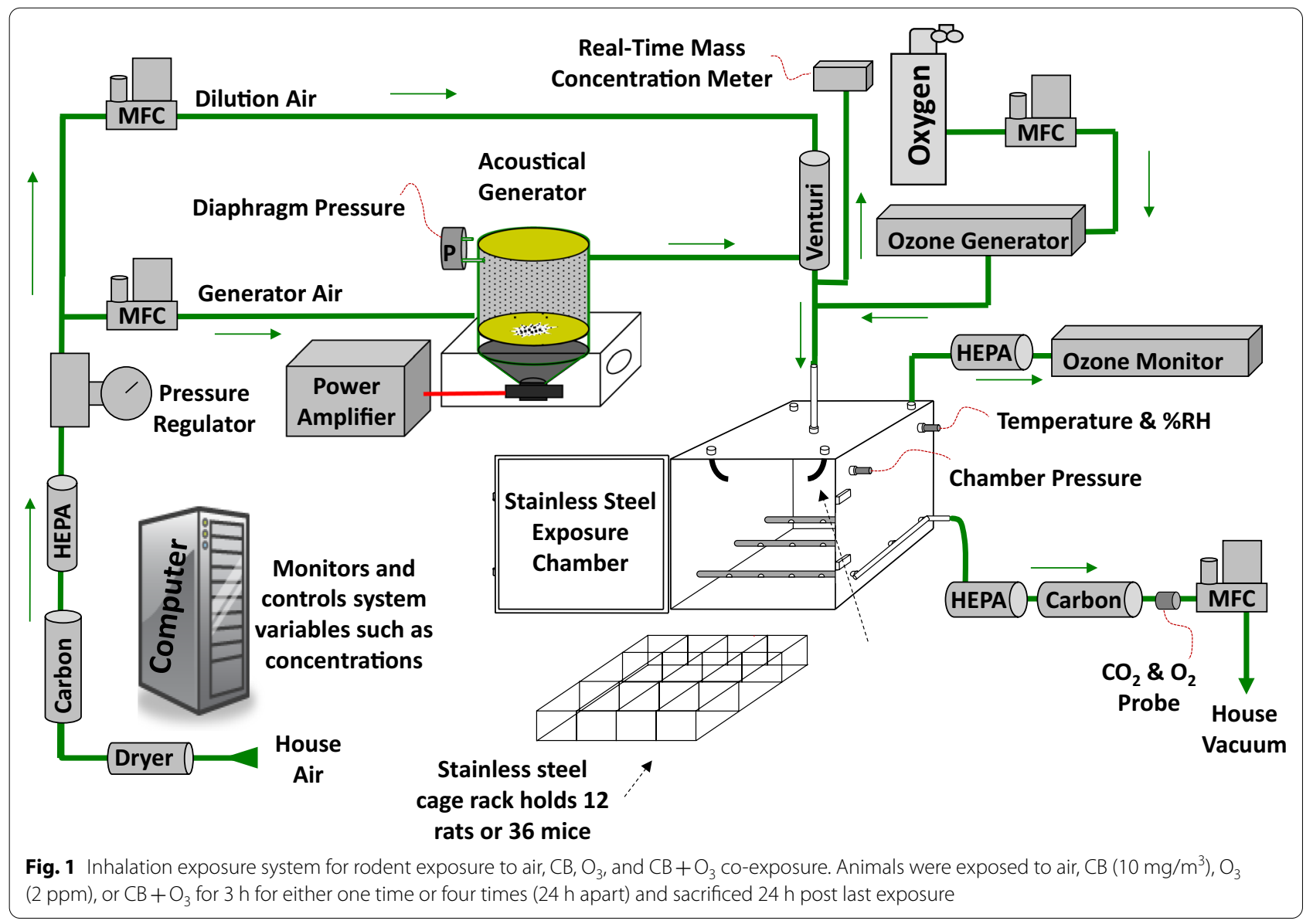


Finland), and pressure (Model 264, Setra Systems, Inc., Boxborough, MA) were measured in real-time within the exposure chamber. The exhaust from the exposure chamber was HEPA and charcoal filtered before entering the facility vacuum exhaust. The entire system was contained within a walk-in hood for technician safety. Software was developed (HPAG, IEStechno, Morgantown, WV) to record and control system variables. Analog inputs and outputs were processed with a multifunction I/O device (USB-6343, National Instruments, Austin, TX).

All airflows were regulated with mass flow controllers (MFCs) (Alicat Scientific, Inc., Tucson, AZ). Multiple real-time feedback loops were utilized within the system. The pressure within the HPAG was measured (Model 264, Setra Systems, Inc., Boxborough, MA) and maintained at $0.5^{\prime \prime} \mathrm{H}_{2} \mathrm{O}$ with the generator MFC input airflow to optimize aerosol generation. The pressure within the exposure chamber was held at $0.0^{\prime \prime} \mathrm{H}_{2} \mathrm{O}$ by regulating the exhaust MFC to provide animal comfort and to prevent leaks. The $\mathrm{CB}$ aerosol mass concentration was maintained by adjusting the acoustical energy levels based on the DataRAM readings and the $\mathrm{O}_{3}$ level was regulated by altering the air/oxygen flow through the ozone generator.

Particle size distributions were measured from the exposure chamber with: 1) an electrical low-pressure impactor (ELPI+, Dakati, Tempera, Finland), 2) an aerosol particle sizer (APS 3321, TSI Inc Shoreview, MN), 3) a scanning mobility particle sizer (SMPS 3938, TSI Inc. Shoreview, MN), and 4) a Nano Micro-orifice Uniform Deposit Impactor (Moudi 115R, MSP Corp, Shoreview, $\mathrm{MN})$. Additionally, aerosols were collected on formvar coated copper grids and the particle surface chemical composition and morphology were inspected with Scanning Electron Microscopy (SEM) (Hitachi S-4700 SEM), Transmission Electron Microscopy (JEOL JEM-2100 TEM) and X-Ray Photoelectron Spectroscopy (XPS) (Physical Electronics PHI 5000 VersaProbe XPS/UPS).

\section{Murine model}

All animal studies, including animal housing, sedation, euthanasia, and experimentation were approved by the West Virginia University Animal Care and Use Committee. These studies conformed to the most current National Institutes of Health (NIH) Guidelines for the Care and Use of Laboratory Animals manual. 8-week-old C57Bl/J6 male mice were purchased from Jackson Laboratory (Bar Harbor, ME) and acclimated at the West Virginia University animal care facility before exposure. All animals were maintained in a room with a 12-h light/dark cycle and provided chow and water ad libitum. Mice were euthanized by intraperitoneal injection of Fatal Plus ${ }^{\circledR}$. 8-week-old $\mathrm{C} 57 \mathrm{Bl} / \mathrm{J} 6$ male mice were randomly divided into four groups: 1) sham/air, 2) $\mathrm{CB}, 3) \mathrm{O}_{3}$, and 4) $\mathrm{CB}-\mathrm{O}_{3}$ co-exposure. Sham animals were exposed to filtered air. Experimental exposures included $10 \mathrm{mg} / \mathrm{m}^{3} \mathrm{CB}$ for $3 \mathrm{~h}$, $2 \mathrm{ppm} \mathrm{O}_{3}$ for $3 \mathrm{~h}$, or co-exposure to $10 \mathrm{mg} / \mathrm{m}^{3} \mathrm{CB}$ and $2 \mathrm{ppm} \mathrm{O}_{3}$ for $3 \mathrm{~h}$. Exposures were either performed once or daily for up to 4 days. Total animals exposed included: sham/air one exposure $(n=4), C B$ one exposure $(n=4)$, $\mathrm{O}_{3}$ one exposure $(\mathrm{n}=4), \mathrm{CB}+\mathrm{O}_{3}$ one exposure $(\mathrm{n}=4)$, sham/air four exposures $(n=8), C B$ four exposures $(n=8), O_{3}$ four exposures $(n=8)$, and $\mathrm{CB}+\mathrm{O}_{3}$ four exposures $(n=8)$. The mice were monitored for changes in weight and euthanized $24 \mathrm{~h}$ after the final exposure (either one or four) for further studies.

The exposure dose for a single ultrafine $\mathrm{CB}$ exposure was chosen to simulate the deposited burden in human lungs after a single 8-h work shift exposure at the current United States Occupational Safety and Health Administration (OSHA) permissible level for CB $\left(3.5 \mathrm{mg} / \mathrm{m}^{3}\right)$. In terms of environmental exposure, considering $24 \mathrm{~h}$ weighted exposure, this translates to a similar amount of CB deposited in 35 days exposure at the current United States National Ambient Air Quality Standard of $35 \mu \mathrm{g} /$ $\mathrm{m}^{3}$. Environmental sources of $\mathrm{CB}$ include fuel combustion leading to release of elemental carbon into the air, release from products such as tires, conveyer belts, rubbers, coatings, and plastics [32-34]. In addition, CB is among the top five highly produced engineered nanomaterials for consumer product applications with production expected to reach approximately 19.2 million metric ton production, worth $\$ 13$ billion market value by 2022 (carbon black user's guide) [14]. These applications, which include printer toners, rubber tires, paints etc., also have significant potential of adding inhalable ultrafine carbon into the environment. Previous $\mathrm{O}_{3}$ deposition studies demonstrate 4-5 times higher rodent exposure doses translate into similar effective doses in controlled exposures to exercising individuals [35, 36]. Thus, our $2 \mathrm{ppm} \mathrm{O}_{3}$ exposure (5 times the 400-ppb dose that induce neutrophilia in humans) is relevant for human exposure extrapolation [36]. Another factor in choosing the $\mathrm{O}_{3}$ dose was to be comparable with the current mechanistic understanding that is mainly generated at the similar levels. Interestingly, few recent reports confirm significant lung inflammation at even lower doses and future studies should aim for better dose response comparisons [37-39]. Given that 91\% of the world population lives in areas where air quality standards are not met and standards are based on time weighted averages, our exposure conditions are certainly relevant for a human exposure scenario [1].

\section{$C B$ lung burden quantification}

$\mathrm{CB}$ lung burden was quantified after a single exposure to estimate deposited lung burden. In brief, air, $\mathrm{CB}$ and 
$\mathrm{CB}+\mathrm{O}_{3}$ groups were euthanized right after a single exposure and the deposited dose in the lungs was quantified by following a previously validated and published method [40].

\section{Lung inflammation}

Following euthanasia, approximately $1 \mathrm{~mL}$ ice cold sterile PBS was instilled through the trachea into the lungs via a syringe three times, obtaining a total broncho-alveolar lavage fluid (BALF) of approximately $3 \mathrm{~mL}$. The cells were counted in the lavage fluid and pelleted by centrifugation at $600 \mathrm{RPM}$ for $5 \mathrm{~min}$ at $4{ }^{\circ} \mathrm{C}$ and used for Cytospin ${ }^{\circledR} 4$ (Thermofisher Scientific) preparation for differential counts. Cells were stained in Hema 3 (Fisher Scientific) and differential as well as absolute counts were made. The lavage fluid supernatant was stored at $-80{ }^{\circ} \mathrm{C}$ for later investigation.

\section{Bronchoalveolar lavage analyses}

Lavage proteins contents were quantified using a Pierce BCA kit (Thermofisher Scientific) according to manufacturer's recommendations.

\section{Lung histopathology and Ki67 immunohistochemistry}

Non-lavaged lungs were fixed by intratracheal instillation of $10 \%$ neutral buffered formalin for histological analyses and 5-micron-thick paraffin-embedded histological sections were stained with hematoxylin and eosin (H\&E) for routine light microscopic examination (VS110, Olympus America). A board-certified veterinary pathologist with experience in respiratory toxicologic pathology of laboratory rodents evaluated the pathological changes without knowledge of individual animal exposure history (blinded manner). Immunohistochemistry was performed on lung tissue sections from formalin-fixed, paraffin embedded, lung lobes to identify nuclear incorporation of Ki67 in bronchiolar epithelial cells undergoing regenerative cell proliferation (1:150, monoclonal rabbit anti Ki67 (SP6), Catalog\#275R-16, Millipore Sigma, Burlington, MA). ATP5F1 levels in the tissue sections were also evaluated using IHC (1:100, ATP5F1 polyclonal antibody, Catalog \# 15999-1-AP, ProteinTech, Rosemont, IL). Immunohistological slides were counterstained with Gill 2 hematoxylin, scanned and digitized with a slide scanner (VS110, Olympus America) before evaluation.

\section{RNA Isolation/real-time PCR}

RNA was isolated from whole lung homogenate after pulverizing the lung tissues at $-80{ }^{\circ} \mathrm{C}$. Total RNA was isolated using a RNeasy Mini Kit (Qiagen) and reverse transcription was performed using a High-Capacity cDNA Reverse Transcription Kit (Thermofisher Scientific). cDNA was diluted to a working concentration of
$10 \mathrm{ng} / \mu \mathrm{l}$. Real-time PCR reaction was performed in triplicate using the AriaMx Real-time PCR System. Primer sequences are provided in Additional file 1. Each PCR reaction mixture contained Syber Green ${ }^{\circledR} 12.5 \mu \mathrm{l}$, cDNA $5 \mu \mathrm{l}$, Primers $3 \mu \mathrm{l}$ and Nuclease Free Water $2 \mu \mathrm{l}$ with a total volume of $22.5 \mu \mathrm{l}$. Relative expression levels were measured using a comparative threshold method using Aria Real-Time PCR Software with $18 \mathrm{~S}$ as internal control. PCR quantification for epithelial alarmins [thymic stromal lymphopoietin (TSLP) and IL-33], inflammatory mediators [interleukin-6 (IL-6), IL-13, tumor necrosis factor- $\alpha$ (TNF- $\alpha)$ ] and lung health indicators [club cell protein 10 (CC10) and surfactant protein-c (SFTPC)] was performed. Data were analyzed using the $2^{-\Delta \Delta C T}$ method [41].

\section{mRNA sequencing/bioinformatics}

RNA was isolated from murine lungs (as described above) and sequenced through the West Virginia University Genomics Core Facility. Libraries were built with the TruSeq ${ }^{\circledR}$ Stranded mRNA Library Prep Kit (Illumina, San Diego, CA) and run on the HiSeq 2500 (Illumina) in 51 bp paired end reads. Fastq files were mapped and quantified using the mapping-based mode of Salmon 1.1.0 [42, 43]. Briefly, a mouse decoy-aware index was created using both the Ensembl primary assembly (release 99) and the transcriptome (release 99). The index was then used to map the paired end reads for quantification, specifying options "--validateMappings" and "--gcBias". Quantification files were imported into $R$ (v3.6.3) using tximeta [44] and differential gene expression performed through DESeq2 [45]. Visualization packages, such as ggplot2 [46], limma [47], vidger [48], EnhancedVolcano [49], and InteractiVenn [50] were implemented. Kyoto Encyclopedia of Genes and Genomes (KEGG), assessed through pathfinder using 10 iterations [51], was used for ontology [52]. Differential gene expression and gene ontology are provided (Additional file 2).

\section{Mitochondrial isolations}

Mitochondria were isolated from the right lung of C57Bl/ J6 male mice using differential centrifugation, as previously detailed [53, 54]. Mitochondria were either immediately used for investigation or stored at $-80^{\circ} \mathrm{C}$ in $\mathrm{KME}$ buffer $(100 \mathrm{mM} \mathrm{KCL}, 50 \mathrm{mM}$ MOPS, and $500 \mu \mathrm{M}$ at $\mathrm{pH}$ 7.4 in water).

\section{Electron transport chain (ETC) complex activities}

Isolated mitochondria (as described above) were used to assess mitochondrial ETC complex activities. Complex I (NADH dehydrogenase, $340 \mathrm{~nm}$ ), complex II (succinate dehydrogenase, $600 \mathrm{~nm}$ ), complex III (cytochrome bc complex, $550 \mathrm{~nm}$ ), complex IV (cytochrome c oxidase), 
and complex V (ATP synthase, $340 \mathrm{~nm}$ ) were evaluated for substrate metabolism spectrophotometrically. Briefly, this included the substrates NADH (complex I), succinate (complex II), cytochrome $\mathrm{C}$ (complex III), reduced cytochrome C (complex IV), and NADH (complex V), coupled with inhibitors of ETC complex activity rotenone (complex I), antimycin a (complex III), and potassium cyanide (complex IV) to determine the activity of each complex. Additional details have been previously described [55]. The Bradford Method [56] was implemented to quantify protein content for normalization of enzymatic activities.

\section{Western blotting}

Immunoblotting was performed using 4-12\% gradient gels through MOPS SDS-PAGE, as previously described [54, 55, 57-60]. Normalization of protein content was assessed using the Bradford Method [56]. Primary antibodies utilized in the study included the following: total OXPHOS Blue Native WV Antibody Cocktail (ab110412) (anti-NDUFA9 (complex I, ab14713, Abcam, Cambridge, MA), anti-SDHA (complex II, ab14715, Abcam), antiUQCRC2 (complex III, ab14745, Abcam), anti-COX IV (complex IV, ab14744, Abcam), and anti-ATP5A (complex V/ATP Synthase, ab14748, Abcam)), anti-ATP5F1 (complex V/ATP Synthase, ab117991, Abcam), and anti-VDAC (\#4866, Cell Signaling Technology, Danvers, MA). Goat anti-mouse IgG (H\&L) horseradish peroxidase (HRP) conjugate 1:10,000 (Thermofisher Scientific) and goat anti-rabbit IgG HRP conjugate 1:5000 (Abcam) were used as the secondary antibodies. Normalization of protein content was through VDAC expression. Chemiluminescence quantified with Radiance Chemiluminescent Substrate (Azure Biosystems, Dublin, CA), per manufacturer's instructions and imaged using the G:Box Bioimaging system (Syngene, Frederick, MD). GeneSnap/ GeneTools software (Syngene) was used to acquire images. Densitometry was analyzed using Fiji Software (NIH, Bethesda, MD).

\section{Mitochondrial electron flow}

The Seahorse XFe96 Electron Flow Assay was performed as described previously [54]. Briefly, the XFe96 instrument was equilibrated at $37{ }^{\circ} \mathrm{C}$ overnight. Isolated lung mitochondria were plated at a density of 2.5 ug per well in the XFe96 culture plate in a volume of $50 \mathrm{uL}$ containing $1 \mathrm{X}$ mitochondrial assay solution (MAS) with $10 \mathrm{mM}$ pyruvate, $2 \mathrm{mM}$ malate, and $4 \mathrm{uM}$ FCCP. MAS is composed of: $70 \mathrm{mM}$ sucrose, $220 \mathrm{mM}$ mannitol, $10 \mathrm{mM}$ $\mathrm{KH}_{2} \mathrm{PO}_{4}, 5 \mathrm{mM} \mathrm{MgCl}, 2 \mathrm{mM}$ HEPES, $1 \mathrm{mM}$ EGTA, and $0.2 \%$ fatty acid free BSA. The XF plate was centrifuged for $20 \mathrm{~min}$ at $2000 \mathrm{RSF}$ in a swinging bucket rotor. After centrifugation, $125 \mathrm{uL}$ of MAS was added to each well to bring each well to a final volume of $175 \mathrm{uL}$. The plate was incubated in a non- $\mathrm{CO}_{2}$ incubator for $10 \mathrm{~min}$. The XF cartridge was prepared for injection for ports $\mathrm{A}$ $(25 \mathrm{uL}), \mathrm{B}(25 \mathrm{uL}), \mathrm{C}(25 \mathrm{uL})$, and D $(25 \mathrm{uL})$. Port A was loaded with rotenone $(20 \mathrm{uM})$, Port $B$ was loaded with succinate $(100 \mathrm{mM})$, Port $C$ was loaded with antimycin-A (40uM) and Port D was loaded with ascorbate (10 mM) and TMPD $(1 \mathrm{mM})$. The cartridge was calibrated by the machine and the assay continued using the protocol developed previously [61]. "Basal" is reported as the mean of the two OCR measurements before rotenone injection for each sample, "Rotenone" is reported as the OCR measurement directly after rotenone injection, "Succinate" is reported as the OCR measurement directly after succinate injection, "Antimycin-A" is reported as the OCR measurement directly after antimycin-A injection, and "Ascorbate/TMPD" is reported as the OCR measurement directly after ascorbate/TMPD measurement. Each group consisted of $n=4$, and each sample had 3 technical replicates.

\section{IPA}

The oxidative phosphorylation pathway was generated through the use of IPA (QIAGEN Inc., https://www.qiage nbioinformatics.com/products/ingenuity-pathway-analy sis) [62].

\section{Hydrogen peroxide $\left(\mathrm{H}_{2} \mathrm{O}_{2}\right)$ quantification}

The $\mathrm{H}_{2} \mathrm{O}_{2}$ levels were quantified from whole lung homogenate using Amplex ${ }^{\mathrm{TM}}$ Red Hydrogen Peroxide/ Peroxidase Assay Kit (Thermo Fisher Scientific, Waltham, MA), following manufacturer's instructions. Briefly, the lung tissues were pulverized at $-80{ }^{\circ} \mathrm{C}$ followed by lysis using RIPA buffer (Thermo Fisher Scientific, Waltham, MA) supplemented with protease inhibitor cocktail (Sigma-Aldrich, St. Louis, MO). The lung proteins were incubated with HRP and Amplex Red dye. The Amplex Red fluorescent dye reacts with $\mathrm{H}_{2} \mathrm{O}_{2}$ to produce the red-fluorescent oxidation product, resorufin. The SpectraMax ${ }^{\circledR}$ iD5 (Molecular Devices, CA) plate reader was used to measure the absorbance at $560 \mathrm{~nm}$ after 45 min of incubation time. All final results were normalized to total protein measured using BCA (bicinchoninic acid) assay kit (Thermo Fisher Scientific, Waltham, MA) for quantification [63].

\section{ATP assay}

The ATP content was quantified from frozen whole lung tissue using ATP Assay Kit (Biovision, Inc. Milpitas, CA), following manufacturer's instructions and previously described protocol [64]. Briefly, frozen lung tissues were pulverized at $-80{ }^{\circ} \mathrm{C}$ followed by homogenization using assay buffer provided by manufacturer. Total Protein 
was quantified using BCA (bicinchoninic acid) assay kit (Thermo Fisher Scientific, Waltham, MA). The standard curve for ATP was generated over a range of $20 \mathrm{nM}$ to $1 \mathrm{nM}$. The phosphorylated glycerol from lung homogenates was measured at $570 \mathrm{~nm}$ using SpectraMax ${ }^{\circledR} \mathrm{iD} 5$ (Molecular Devices, CA) plate reader after incubation with the probe for approximately $90 \mathrm{~min}$. All results were normalized to total protein measured using BCA (bicinchoninic acid) assay kit (Thermo Fisher Scientific, Waltham, MA) for quantification.

\section{Statistics}

Statistical differences were inferred using Analysis of Variance (ANOVA) followed by a Tukey's post-hoc test, a two-sided Student's t-test, or mixed-effects model, where appropriate using GraphPad Prism ${ }^{\circledR} 7.0$ software. The mixed-effects model applied Dunnett's multiple comparison test, with a single pooled variance, for statistical assessments of data containing both duration of exposure and type of exposure as variables. Differences between groups were considered statistically significant if $P \leq 0.05$, denoted by *. Data are presented as the mean \pm standard error of the mean (SEM), when appropriate. For mRNA sequencing, normalized counts $>2$ in more than three samples were considered in statistical analyses. Significance for sequencing results were set to a $P$ adjusted value $\left(P_{a d j}\right) \leq 0.05$. The false-discovery rate $(\mathrm{FDR})$ was set to 0.05 and statistical testing was performed through the Wald test.

\section{Results}

\section{Exposure characteristics}

Real-time monitoring of $\mathrm{CB}$ and $\mathrm{O}_{3}$ levels inside the exposure chamber confirmed the generation of stable aerosols (Fig. 2A). The aerosols $\left(\mathrm{CB}\right.$ and $\left.\mathrm{CB}+\mathrm{O}_{3}\right)$ collected on filters were analyzed for morphology by TEM and SEM (Fig. 2B-E). Concurrent SMPS/APS measurements confirmed that the majority of the particle in the generated aerosols were in the ultrafine/nano range with a count median diameter of $82.9 \mathrm{~nm}$ and $84.6 \mathrm{~nm}$ with geometric standard deviations of 2.46 and 2.50 , respectively for $\mathrm{CB}$ and $\mathrm{CB}+\mathrm{O}_{3}$ aerosols (Fig. 2F). ELPI + measurements, which are based on charge, resulted in count median diameters of 64.5 and $74.4 \mathrm{~nm}$ with geometric standard deviation of 2.12 and 2.22, respectively for $\mathrm{CB}$ and $\mathrm{CB}+\mathrm{O}_{3}$ aerosols (Fig. 2G). Aerosol mass based MOUDI measurements indicated mass median diameters of 0.90 and $1.10 \mu \mathrm{m}$ with a geometric standard deviation of 2.62 and 3.06, respectively for $\mathrm{CB}$ and $\mathrm{CB}+\mathrm{O}_{3}$ aerosols (Fig. $2 \mathrm{H}$ ). We quantified $\mathrm{CB}$ lung burden after a single exposure to be $2.2 \pm 0.2 \mu \mathrm{g} / \mathrm{lung}$ at the end of a single exposure both in the case of $\mathrm{CB}$ and $\mathrm{CB}+\mathrm{O}_{3}$ inhalation. This burden translates into one day of human exposure at current OSHA-PEL or 35 days of exposure at the current United States National Ambient Air Quality Standard of $35 \mu \mathrm{g} / \mathrm{m}^{3}$ (considering $24 \mathrm{~h}$ weighted exposures).
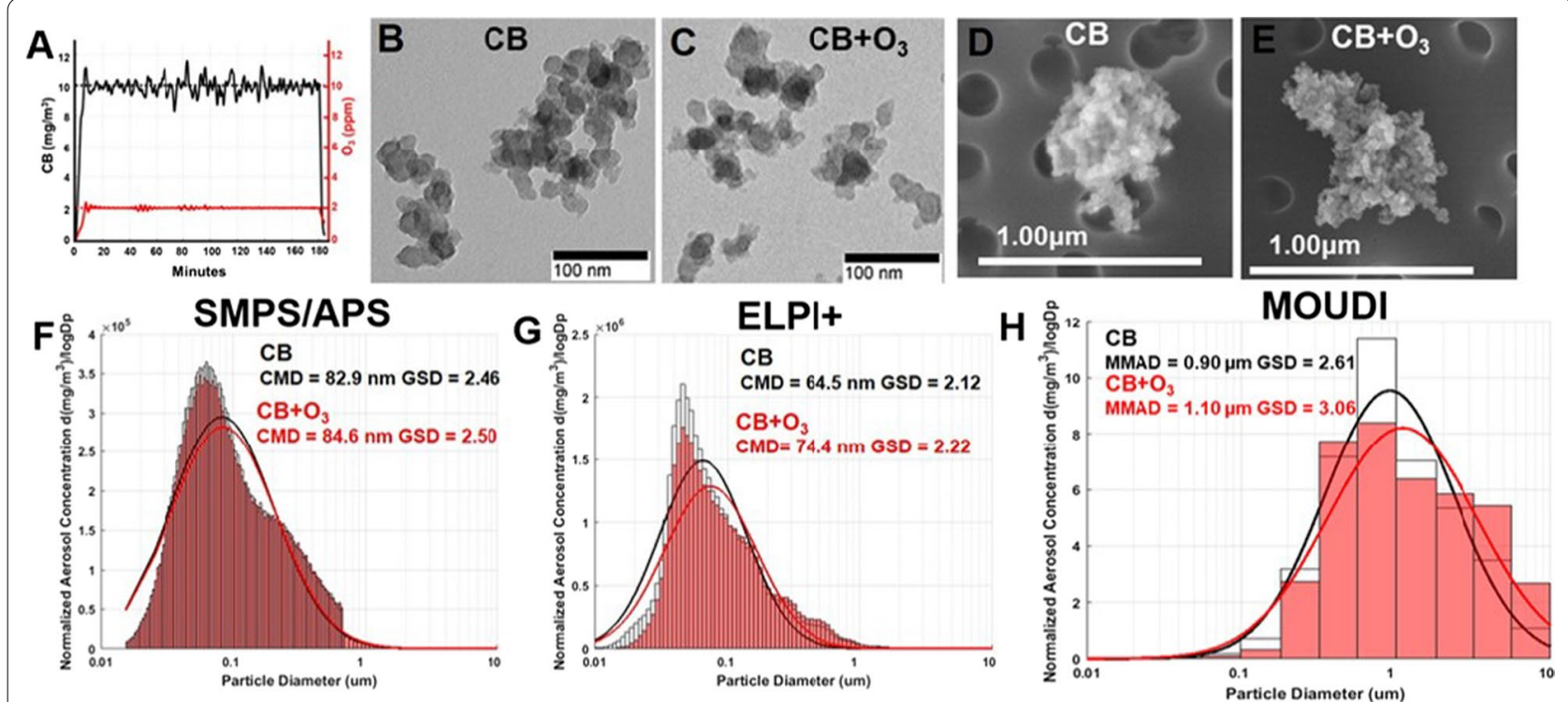

Fig. 2 Exposure aerosol monitoring and characterization. A Real-time monitoring of $\mathrm{CB}$ and $\mathrm{O}_{3}$ levels in the exposure chamber during exposure. Representative TEM and SEM images of $\mathbf{B}, \mathbf{D} C B$ and $\mathbf{C}, \mathbf{E} C B+\mathrm{O}_{3}$ aerosol particles collected from inhalation chamber, respectively. Representative figures of aerosol size distribution and log normal distribution fits on data collected using F SMPS/APS (Scanning Mobility Particle Sizer/ Aerodynamic Particle Sizer) G ELPI+ (Electrical Low Pressure Impactor) and H MOUDI (Micro-orifice Uniform Deposit Impactor) 

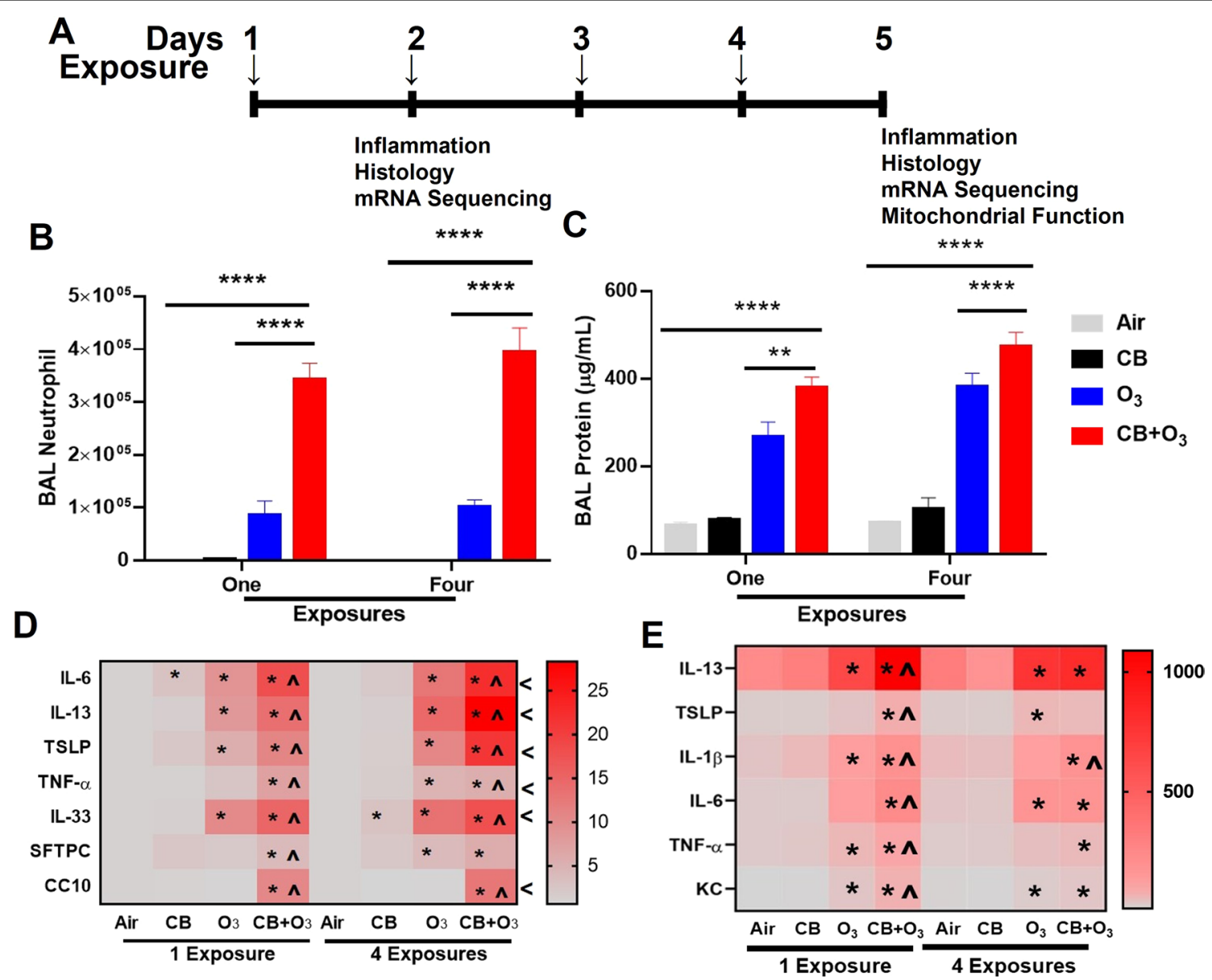

Fig. 3 Exposure design and analysis of lung inflammation. A Layout of animal exposure experiments. B Number of polymorphonuclear leukocytes-neutrophils in bronchoalveolar lavage fluid. C Total protein quantification of bronchoalveolar lavage. D Real-time PCR analysis of mRNA expression (fold change) in lung homogenates, and $\mathbf{E}$ Bronchoalveolar lavage cytokine concentrations (pf/mL) by ELISA assay at $24 \mathrm{~h}$ post single and four exposures. Animals were exposed to air, $\mathrm{CB}\left(10 \mathrm{mg} / \mathrm{m}^{3}\right), \mathrm{O}_{3}(2 \mathrm{ppm})$, or $\mathrm{CB}+\mathrm{O}_{3}$ for $3 \mathrm{~h}$ for either one time or four times ( $24 \mathrm{~h}$ apart) and euthanized $24 \mathrm{~h}$ post last exposure. Data are presented as the mean \pm standard error of the mean (SEM) and analyzed by two-way Analysis of Variance (ANOVA) followed by Turkey's post hoc test. There were $n=4-5$ animals per group and per timepoint were used for these analyses. Where ${ }^{*} P \leq 0.05,{ }^{* *} P \leq 0.01,{ }^{* * *} P \leq 0.001,{ }^{* * *} P \leq 0.0001$. PCR Analyses (panel $\mathrm{D}$ ) ${ }^{*}$ denotes significantly different from air/sham, $\wedge$ denotes significantly different from $\mathrm{O}_{3}$ at same time point, and ' denotes significantly different between day one and four exposures

\section{Pulmonary inflammation and permeability}

A layout of the experimental design is presented in Fig. 3A. Both single or multiple exposures to $\mathrm{O}_{3}$ and $\mathrm{CB}+\mathrm{O}_{3}$ induced a significant increase in lung lavage cellularity, as indicated by a significant increase in number of total lavage cells and macrophages (Additional file 3: Fig. $\mathrm{S} 1 \mathrm{~A}-\mathrm{B})$. A greater and persistent increase in lavage neutrophils was induced by co-exposure compared with $\mathrm{O}_{3}$ only exposure (Fig. 3B). Moreover, a significantly greater and persistent increase in lung lavage total protein contents by co-exposure aerosol inhalation and to a lesser extent by $\mathrm{O}_{3}$ inhalation further confirmed deleterious impacts in terms of an increase in air-blood barrier permeability (Fig. 3C). Real-time mRNA expression analyses of the lung tissue homogenates further confirmed significant increase in mRNA expression of several markers for injury (SFTPC, CC10), epithelial alarmins (TSLP, IL-33), and inflammatory mediators (IL-33, TSLP, IL-1 $\beta$, TNF- $\alpha$, IL-6, IL-13) (Fig. 3D). These mRNA expression studies confirmed that compared to individual exposures, coexposure aerosols have significantly greater potency to induce transcriptional changes both following single and repeated exposures. Inflammatory cytokine proteins (IL6 , KC, TNF- $\alpha$, IL-1 $\beta$ ) concentration in bronchoalveolar lavage were significantly increased by co-exposure compared with $\mathrm{CB}$ and $\mathrm{O}_{3}$ single as well as repeated exposures (Fig. 3E). CB inhalation at the tested doses failed to induce an increase in lavage cellularity and total proteins, 
only inducing mRNA expression of IL-6 after single exposure and IL-33 after repeated exposures.

\section{Histopathology for $\mathrm{CB}, \mathrm{O}_{3}$, and co-exposure}

Sham mice exposed to filtered air had no pulmonary histopathology after either a single one-day (3 h) (Fig. 4A) or a repeated four-day ( $3 \mathrm{~h} /$ day) inhalation exposure (data not shown). Mice acutely exposed to $10 \mathrm{mg} / \mathrm{m}^{3}$ $\mathrm{CB}$ had no inflammatory or epithelial lung lesions, but there were conspicuous small black particles in alveolar macrophages most prominent in centriacinar regions, but also widely scattered in the alveolar parenchyma of the lung lobes (Fig. 4B). In addition, a few extracellular $\mathrm{CB}$ aggregates were observed in alveolar airspaces. In the

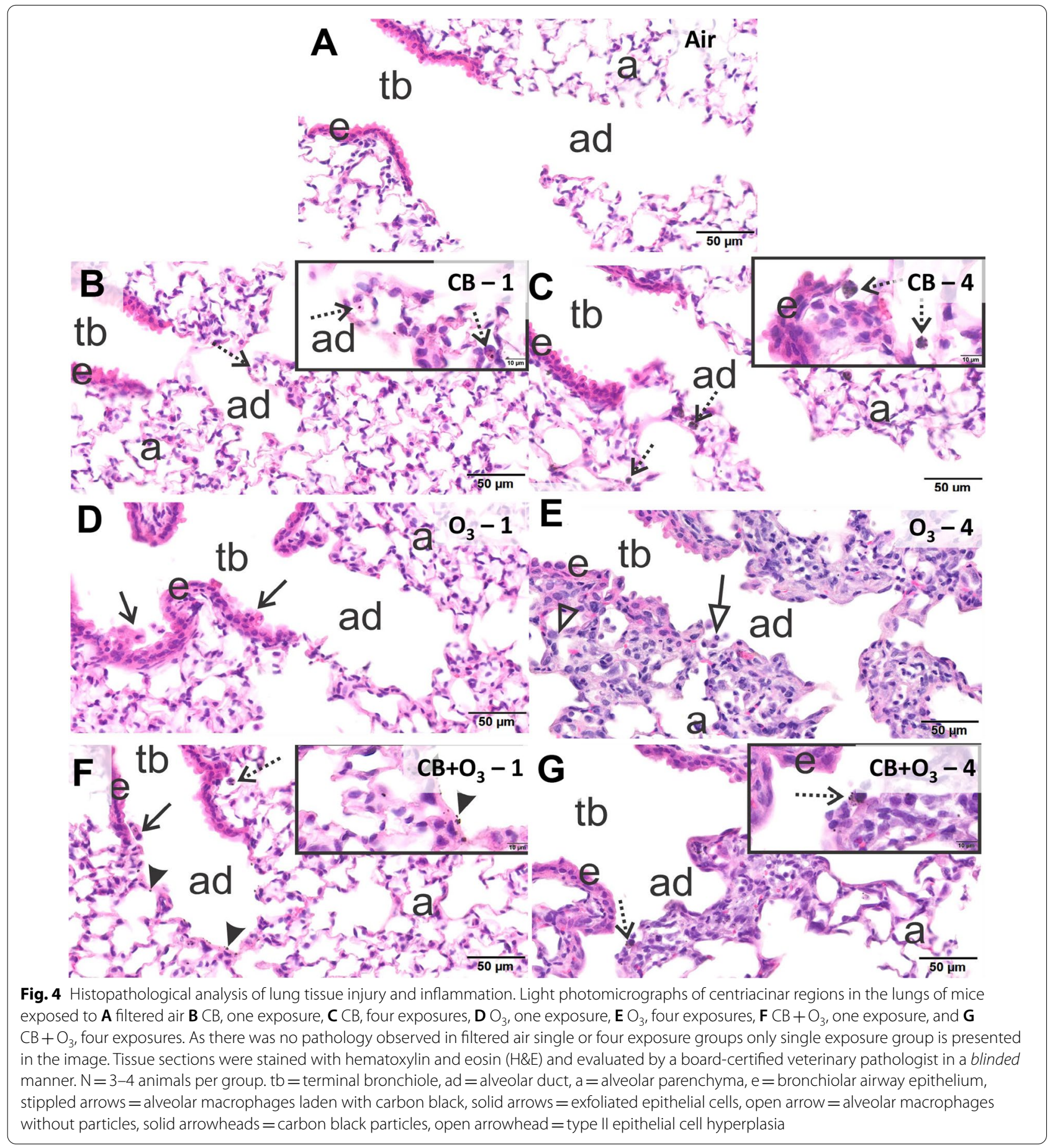


lungs of mice exposed for four days to $\mathrm{CB}$, there were slightly more macrophages and more macrophages heavily laden with CB (Fig. 4C). Like in mice acutely exposed to $\mathrm{CB}$, there was no associated inflammatory cell influx, e.g., neutrophils, in the lungs of these animals. In contrast animals exposed for one day to $2 \mathrm{ppm}_{3}$ had mild multifocal areas of bronchiolar epithelial cell necrosis with exfoliation near some airway branching sites in proximal large-diameter and small-diameter preterminal bronchioles throughout the lung lobes. Similar epithelial necrosis was evident in a few terminal bronchioles (Fig. 4D). After four consecutive days of exposure to $\mathrm{O}_{3}$, mice had more pronounced centriacinar lesions consisting of a thinner airway epithelium lining terminal bronchioles that was characterized by low basophilic cuboidal to squamoid, nonciliated, club cells and a noticeable decrease in the number of ciliated cells (Fig. 4E). Proximal alveolar ducts and adjacent alveoli had thickened alveolar septa and hyperplasia of type two alveolar epithelial cells. In conjunction with these later lesions there were also increases in alveolar macrophages/monocytes and a few widely scattered neutrophils (Fig. 4E).

Mice that received a single 3-h co-exposure to $\mathrm{O}_{3}$ and CB had multifocal areas of bronchiolar epithelial necrosis in preterminal and terminal bronchioles (lesions similar to those in mice acutely exposed to $\mathrm{O}_{3}$ ) (Fig. 4F). In addition, there were also alveolar macrophages containing $\mathrm{CB}$ particles as well as extracellular particles that were predominantly located in centriacinar regions (Fig. 4F). Mice co-exposed to $\mathrm{O}_{3}$ and $\mathrm{CB}$ for four days had similar centriacinar ozone lesions as described above for mice exposed only to $\mathrm{O}_{3}$ for four days (Fig. 4G). In addition, CB-laden macrophages as well as cell free CB were conspicuous in centriacinar regions throughout the lung lobes of these co-exposed animals. Based on the severity of the histological change's groups were classified from most severe to least severe as follows: $\mathrm{CB}+\mathrm{O}_{3}-4>\mathrm{O}_{3}-4>\mathrm{CB}+\mathrm{O}_{3}-1$ $\geq \mathrm{O}_{3}-1>\mathrm{CB}-4>\mathrm{CB}-1$. This severity grading was assigned taking into consideration epithelial necrosis, carbon laden macrophage, centriacinar inflammation and epithelial hyperplasia.

\section{NADPH oxidase pathway changes and hydrogen peroxide levels}

We evaluated NADPH oxidase pathway related gene expression to evaluate whether this pathway was altered during inhalation exposures. A significant upregulation of mRNA expression for Nox2, Duox2, p40 ${ }^{\text {phox }}$, and $\mathrm{p} 47^{\text {phox }}$ was observed (Fig. 5A). A trend for increase was observed for Nox1 gene expression. The gene expression of two well-known oxidative stress responsive proteins [heme oxygenase-I (HO-1), and Thioredoxin 1(Txn-1)] further indicated a significant and robust adaptive gene expression response induction after single exposure which was still active after four day exposure. We performed Amplex Red assay to quantify the amount of $\mathrm{H}_{2} \mathrm{O}_{2}$ in the lung tissue and found significantly greater increase by $\mathrm{CB}+\mathrm{O}_{3}$ exposure after single exposure compared with other individual exposures (Fig. 5B).

\section{Bioinformatics assessing the duration and exposure of $C B$, $\mathrm{O}_{3}$, and co-exposure}

To understand the interaction between duration of exposure (i.e., one day versus four consecutive days) and type
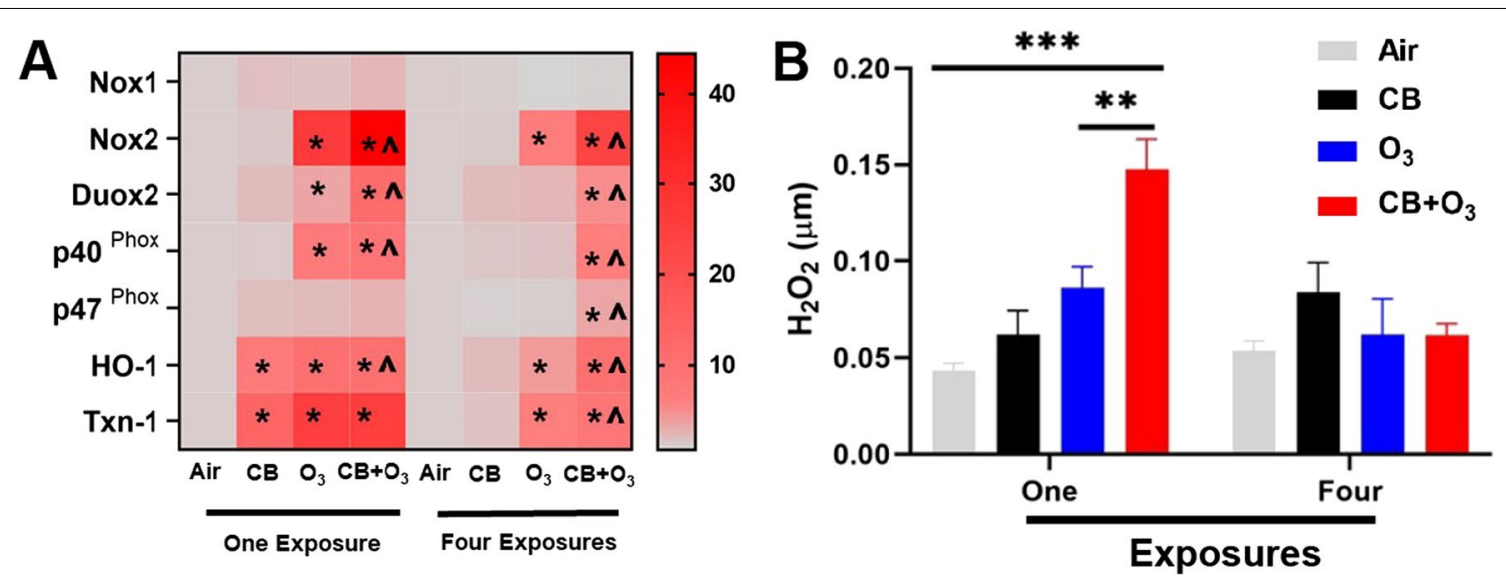

Fig. 5 Changes in Nicotinamide Adenine Dinucleotide Phosphate (NADPH) pathway in air, $C B, \mathrm{O}_{3}$, and $C B+\mathrm{O}_{3}$ co-exposed mice. A Real-time $P C R$ analysis of mRNA expression (fold changes) in the lung homogenates $\mathbf{B}$ hydrogen peroxide $\left(\mathrm{H}_{2} \mathrm{O}_{2}\right)$ concentration measured by Amplex Red assay in the lung homogenates. For these studies experimental design and exposure concentrations are the same as reported in Fig. 3. Data are presented as the mean \pm standard error of the mean (SEM) and analyzed by two-way Analysis of Variance (ANOVA) followed by Turkey's post hoc test. There were $n=5-7$ animals per group and per timepoint were used for these analyses. Where ${ }^{*} P \leq 0.05,{ }^{* *} P \leq 0.01,{ }^{* * *} P \leq 0.001,{ }^{* * *} P \leq 0.0001$. $P C R$ Analyses (panel A) * denotes significantly different from air/sham, $\wedge$ denotes significantly different from $\mathrm{O}_{3}$ at same time point 


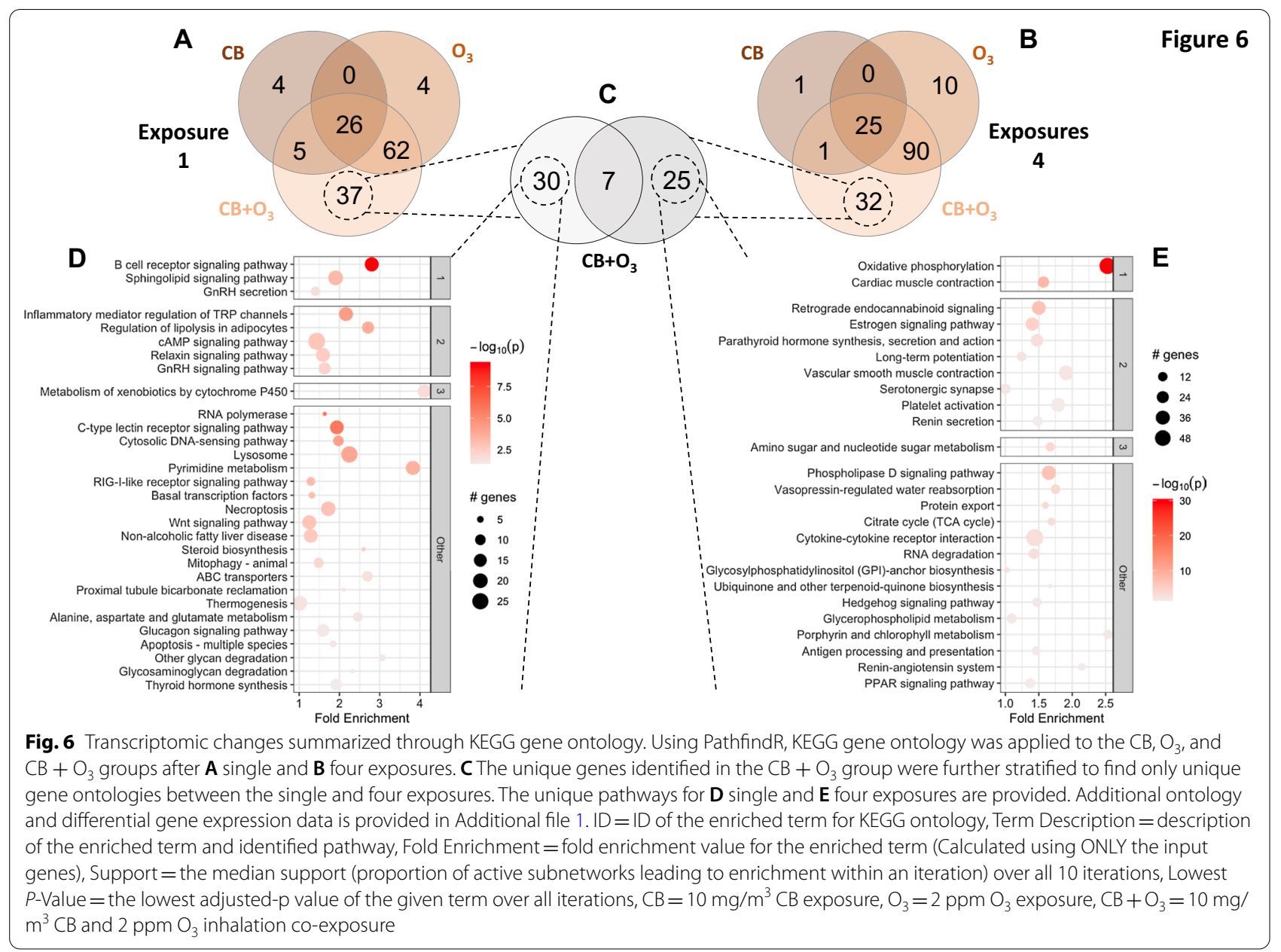

of exposure $\left(\mathrm{CB}, \mathrm{O}_{3}\right.$, or co-exposure) we utilized gene ontology (Fig. 6). The process of integrating gene level changes into pathway analyses first required appreciating how these groups clustered through principal component analysis (PCA) (Additional file 4: Fig. S2A). PCA illustrated that the duration of exposure impacted differential gene expression the most, indicated by the percent variance on the $x$-axis between groups (Additional file 4: Fig. S2A). Using a differential expression matrix, we further highlighted that four exposures to $\mathrm{CB}+\mathrm{O}_{3}$ revealed the highest degree of differentially expressed genes when compared to day one exposures of air $(5,323), \mathrm{O}_{3}(5,532)$, and CB $(6,294)$ (Additional file 4: Fig. S2B). Additionally, following four exposures, the $\mathrm{CB}+\mathrm{O}_{3}$ and $\mathrm{O}_{3}$ groups showed a significant upregulation of the top 50-100 genes differentially regulated in the analysis (Additional file 4: Fig. S2C, top of heatmap). While we only include a heatmap of the top 500 genes for reference, we have also assessed gene combinations ranging from 50 to 5000 genes (https://github.com/qahathaway/Co-Exposure/ tree/main/Heatmaps). These data illustrate that the Day
4 CB- $\mathrm{O}_{3}$ and $\mathrm{O}_{3}$ groups have very distinct expression profiles that are hierarchically separate from the other groups, regardless of the number of genes assessed.

Next, we needed to understand how the genes were being differentially expressed per group. Volcano plots including all genes for $\mathrm{CB}, \mathrm{O}_{3}$, and $\mathrm{CB}+\mathrm{O}_{3}$ at days one and four illustrate the expression profile of all genes analyzed (Additional file 5: Fig. S3). Venn diagrams capturing the number of differentially expressed genes that are shared or unique to the exposures for both single (Additional file 6: Fig. S4A) and four (Additional file 6: Fig. $\mathrm{S} 4 \mathrm{~B})$ exposures are provided. The $\mathrm{CB}+\mathrm{O}_{3}$ co-exposure had the most differentially regulated genes, including the most uniquely altered genes. The uniquely expressed genes in co-exposure for single (Additional file 6: Fig. S4C) and four (Additional file 6: Fig. S4D) exposures are captured in volcano plots. Co-exposure of $\mathrm{CB}+\mathrm{O}_{3}$ incites a unique transcriptomic response that cannot be captured by an understanding of the toxicology produced from exposure to either of the toxicants alone. 


\section{Unique transcriptomic responses defining co-exposure}

The transcriptomic profile of $\mathrm{CB}+\mathrm{O}_{3}$ is distinctly unique, compared to $\mathrm{CB}$ or $\mathrm{O}_{3}$ individually, so we wanted to investigate if these regulatory changes were indicative of changes in cellular pathways. Gene ontology through KEGG summarized the differential gene expression data into a more comprehensible assessment of what alterations occur at single (Fig. 6A) and four (Fig. 6B) exposures, represented as Venn diagrams. These Venn diagrams illustrate how $37\left(\mathrm{CB}+\mathrm{O}_{3}\right.$, one exposure) and $32\left(\mathrm{CB}+\mathrm{O}_{3}\right.$, four exposures $)$ cellular pathways are unique in co-exposure. We further examined the similarities/dissimilarities of the unique co-exposure pathways (Fig. 6C) and show each of the non-overlapping pathways for single (Fig. 6D) and four (Fig. 6E) exposures. We also provide the overlapping ontologies of all groups in a 6-way Venn diagram (Additional file 7: Fig. S5A) to allow for further appreciation of the stratification of the groups, as well as the 3 pathways that overlap between all groups, and a few of the representative genes (Additional file 7: Fig. S5B). Additionally, all differential expression and gene ontology data are provided (Additional file 2). The pathways represented in Fig. 6D, E reveal a variety of different functions in the cell, so we focused more specifically on the top (lowest $P$-value) pathways. Following single exposure, B cell signaling pathways were altered, highlighting the importance of immune processes engaged during pulmonary insult from xenobiotic particles (Fig. 6D). Interestingly, after four days of exposure, mitochondrial oxidative phosphorylation was the top pathway (Fig. 6E). While activation of immune function is commonly associated with inhaled toxicants, changes in pulmonary metabolism suggest a unique mechanism for adaptation/maladaptation to sustained particle inhalation.

\section{Lung proliferation after $\mathrm{CB}-\mathrm{O}_{3}$ co-exposure}

With transcription of mitochondrial proteins altered, we wanted to know if this was part of a general response initiated by increases in cellular replication. Proliferating cells in the lung sections were immunostained with Ki-67. We observed minimal proliferative response in air exposed mice lungs (Fig. 7A, B), mild Ki67 staining in mice co-exposed to $\mathrm{CB}$ and $\mathrm{O}_{3}$ for one day (Fig. $7 \mathrm{C}$, D), and marked Ki67-stained nuclei in mice similarly co-exposed for four days (Fig. 7E, F). Interestingly, when looking at all pathways, unique or common, Ingenuity Pathway Analysis (IPA) revealed that the most significantly expressed $(\mathrm{P} \leq 0.001)$ canonical pathway after four exposures to $\mathrm{CB}+\mathrm{O}_{3}$ was related to microtubule formation and mitosis (Fig. 7G). Agreeing with the histological

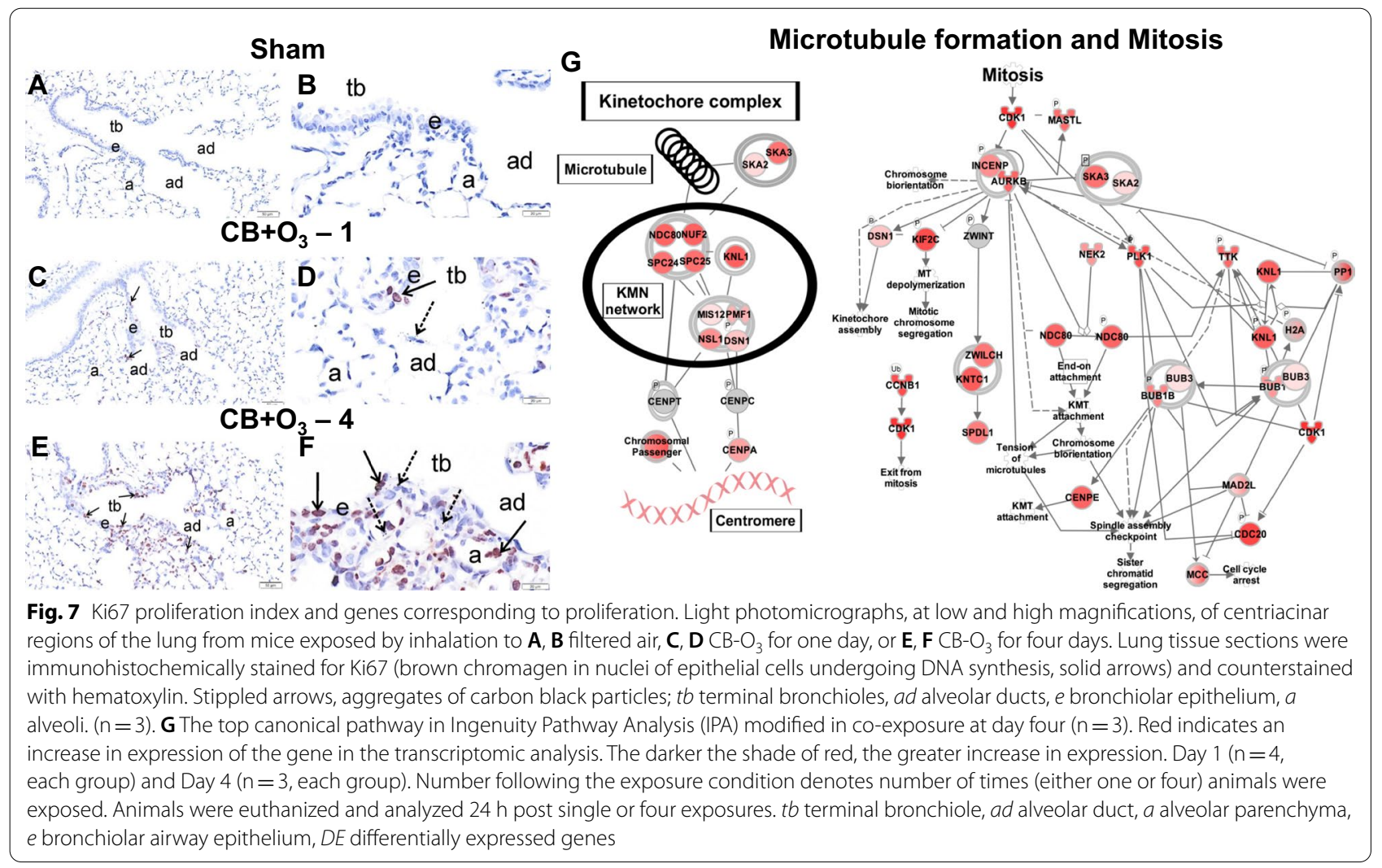


presentation of the group, the IPA schematic reveals likely molecular players involved in modulating the proliferation response following co-exposure.

\section{Mitochondrial electron transport chain (ETC) and electron flow}

$\mathrm{CB}+\mathrm{O}_{3}$ co-exposure over four days results in an increased transcription of mitochondrial genes (Additional file 2), so we wanted to understand how this correlates with mitochondrial function. ETC maximal activities were measured for each complex (Fig. 8A-E). After four exposures, alterations were seen in complex I with $\mathrm{CB}, \mathrm{O}_{3}$, and $\mathrm{CB}+\mathrm{O}_{3}$ (Fig. 8A), complex II with $\mathrm{O}_{3}$ and $\mathrm{CB}+\mathrm{O}_{3}$ (Fig. 8B), none in complex III (Fig. 8C), complexes IV with $\mathrm{O}_{3}$ and $\mathrm{CB}+\mathrm{O}_{3}$ (Fig. 8D), and ATP Synthase with $\mathrm{CB}+\mathrm{O}_{3}$ (Fig. 8E). Using IPA, we illustrated genes involved in the mitochondrial ETC/oxidative phosphorylation pathway for $\mathrm{CB}+\mathrm{O}_{3}$ and overlayed this information with ETC activity represented as percent change from the control group (Fig. 8F). After four days of exposure, $\mathrm{CB}+\mathrm{O}_{3}$ co-exposure resulted in differential expression of 35 genes in the mitochondrial ETC pathway (Fig. 8F).

Observing changes in both the RNA expression and mitochondrial function of the mitochondrial ETC, we next broadly evaluated protein content of the complexes (Fig. S6A). Examining NDUF9A (complex I), SDHA (complex II), UQCRC2 (complex III), COXIV (complex IV), and ATP5A (complex V) protein content, obeserving no changes between the $\mathrm{CB}+\mathrm{O}_{3}$ and air groups (Additional file 8: Fig. S6B-F). Additionally, we examined if mRNA expression was representative of protein expression for transcripts known to be altered. Immunoblotting of an ATP Synthase subunit, ATP5F1, in isolated mitochondria revealed decreased content in the $\mathrm{CB}+\mathrm{O}_{3}$ group (Fig. 8G), in contrast to an increased mRNA

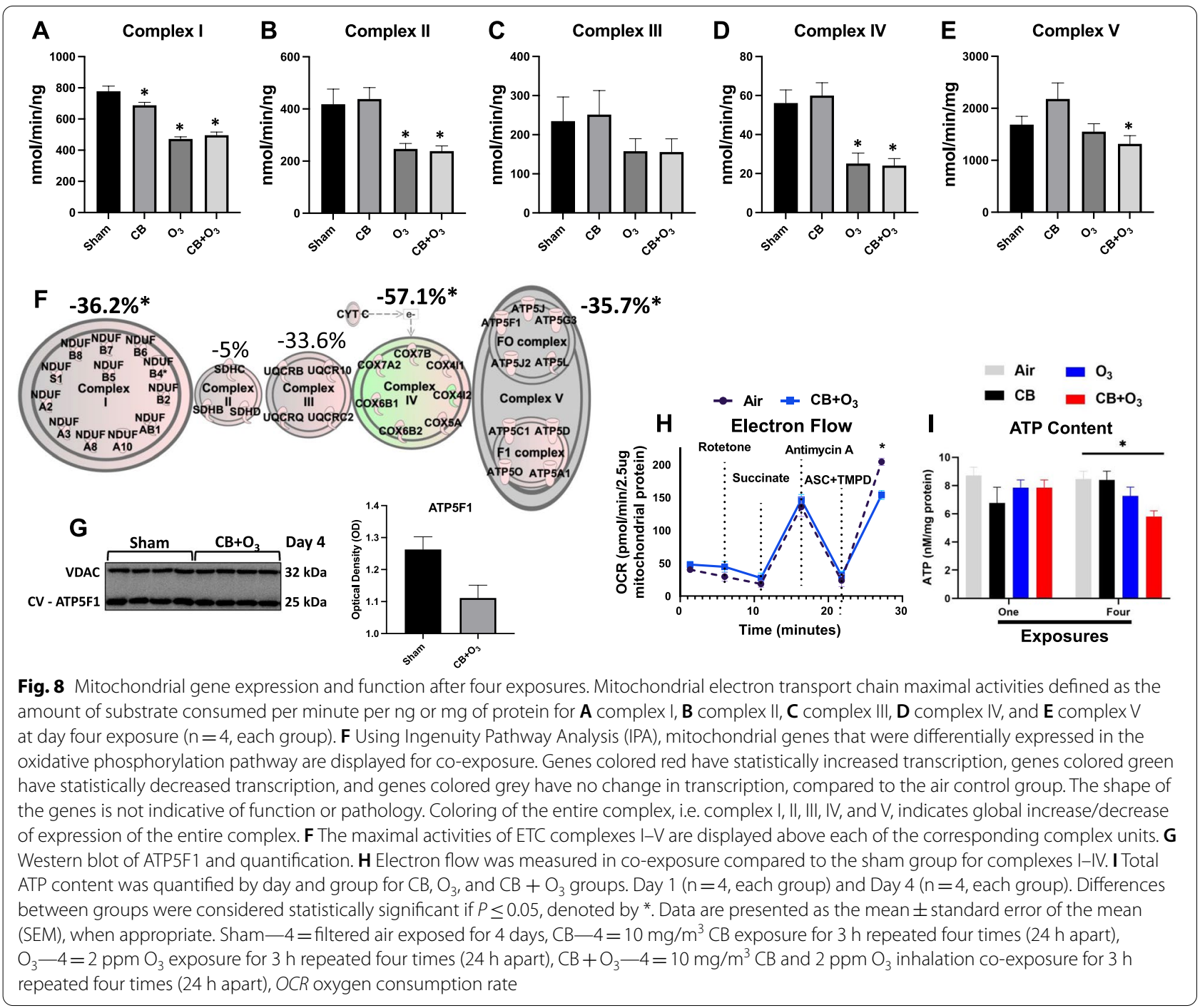


expression (Fig. 8F). We further performed IHC on the lung tissue for ATP5F1 which indicated an increased expression in the lung areas/cells showing significant alterations such as bronchiolar epithelium and weaker expression was noted in alveolar macrophages (Additional file 9: Fig. S7). This discrepancy pointed towards a potential import issue for this protein into the mitochondria. We further evaluated ATP Synthesis in the $\mathrm{CB}+\mathrm{O}_{3}$ co-exposure group, assessing electron flow through complexes I-IV to identify if mitochondrial coupling was also dysfunctional (Fig. 8H). The flow of electrons was significantly diminished through complex IV in the coexposure, as illustrated by a decreased oxygen consumption rate $(\mathrm{OCR})$ when ascorbate and TMPD were added. Additionally, the total ATP content of the lung was significantly decreased after four exposures in the $\mathrm{CB}+\mathrm{O}_{3}$ group (Fig. 8I). While co-exposure increases expression of mitochondrial transcripts, an imbalance in protein production and a decrease in electron flow efficiency of mitochondria are present.

\section{Discussion}

This study validated interactive transcriptomic alterations induced by inhalation co-exposure to $\mathrm{CB}$ and $\mathrm{O}_{3}$. Our approach involved first identifying which cellular pathways were significantly impacted following co-exposure, i.e., transcriptomics, followed by testing the validity of these initial findings, i.e., through biochemical, histological, and molecular assessments. In examining the uniquely expressed transcripts after inhalation co-exposure, we identified and validated two critical pathways: mitochondrial oxidative phosphorylation and cellular proliferation. A decrease in mitochondrial function is likely a crucial factor in driving the maladaptive response following co-exposure. This study has significant merit compared with the published literature as this is the first detailed evaluations of unique transcriptomic signature of a particulate and gaseous inhalation co-exposures.

We intentionally decided to use $\mathrm{CB}$ and not black carbon $(\mathrm{BC})$ or the particulate matter (PM) collected from environmental sampling. This choice was made since, 1) composition of $P M$ varies significantly over a given period depending upon factors, such as, season, temperature, humidity, source of combustion, and other environmental contaminants e.g., endotoxin, pollen etc., and 2) $\mathrm{BC}$ is an already modified carbon material after interacting with $\mathrm{O}_{3}, \mathrm{NOx}$, and hydrocarbons from combustion [65]. Both materials, while environmentally relevant, cannot simulate individual interactions between different constituents. Indeed, a recent study confirmed that interaction with $\mathrm{O}_{3}$ modifies the composition of PM [6]. Our model simplistically confirms the potential of interactions between the ultrafine particles of $\mathrm{CB}$ (a low toxicity low solubility material) and $\mathrm{O}_{3}$, and thus provides basis for further research by adding additional constituents of air pollution.

Histology and inflammation data clearly indicate the increased toxic potential of co-exposure. While these data failed to provide unique alterations induced by coexposure, they confirmed significantly greater potential for inhalation co-exposure to induce lung injury and inflammation. In addition, these results are in line and confirm previous rodent studies and human controlled exposure studies for $\mathrm{O}_{3}$, indicating lung inflammation and injury [36, 66, 67]. A significant increase in lung $\mathrm{PMN} /$ neutrophil levels after a single co-exposure was further aggravated after multiple exposures. Interestingly, in the case of $\mathrm{O}_{3}$, multiple exposures did not further enhance this response. It is not surprising, as previous studies show that respiratory alterations, such as neutrophil accumulation, to acute ozone exposure paradoxically resolve during multiple exposure scenarios due to a failure in the mechanisms leading to accumulation of neutrophils at the site of inflammation [68, 69]. Conversely, an obvious synergistic accumulation of neutrophils at both times is evident for $\mathrm{CB}+\mathrm{O}_{3}$ co-exposure. This indicates that the mechanisms that led to an impaired increase in neutrophils in the case of $\mathrm{O}_{3}$ exposure are no longer effective [70].

Increased expression of epithelial alarmins (IL-33 and TSLP), inflammatory mediators (IL-6, TNF- $\alpha$, IL-13, IL-1 $\beta)$ and lung injury/health markers (CC10, SFTPC) clearly indicate the potential of co-exposure to induce these signaling pathways. CC10 and SFTPC are not only markers of unique cell families in terminal bronchioles and alveoli but are also associated with a variety of pulmonary disorders ranging from interstitial lung diseases to cancer and environmental exposures [66, 71-74]. A previous study demonstrated serum $\mathrm{CC} 10$ levels as a sensitive biomarker of $\mathrm{O}_{3}$-induced changes in the airway epithelium [71]. Interestingly, we only observed altered gene expression in the $\mathrm{CB}+\mathrm{O}_{3}$ co-exposure group at $24 \mathrm{~h}$ post exposure. Since the current study focused on mRNA expression and employed a different time point and ozone exposure concentration, it is plausible that the observed response is a result of co-exposure-induced altered kinetics for $\mathrm{CC} 10$ gene expression. Inflammatory cytokine proteins (IL-6, KC, TNF- $\alpha$, IL-1 $\beta$ ) concentration measurement in bronchoalveolar lavage by ELISA confirmed significantly greater potentials of co-exposure to induce cytokine production.

Mitochondrial functional impairments, such as decreases in bioenergetics, can be attributed to changes in coupling efficiency, ETC integrity, substrate availability, and other similar mechanisms. Mitochondrial 
function is known to be altered following $\mathrm{CB}$ and $\mathrm{O}_{3}$ exposure. $\mathrm{CB}$ exposure is linked to mitochondrial dysfunction through the inhibition of mitochondrial fission/fusion [75] and increased mitochondrial damage (observed as cytochrome c release) [76]. $\mathrm{O}_{3}$ exposure is also known to cause mitochondrial damage, through damaging mtDNA in vascular mitochondria [77], but has also been identified in regulating bioenergetics [78]. Valdez et al. indicated that mitochondrial ETC complex activities in the brain are decreased following pulmonary $\mathrm{O}_{3}$ exposure, with diminished activity of complex IV as one of the primary findings. Our results further support the concept that $\mathrm{O}_{3}$, as well as $\mathrm{CB}+\mathrm{O}_{3}$, inhalation exposure results in decreased complex IV activity.

Contrary to the individual $\mathrm{CB}$ or $\mathrm{O}_{3}$ exposures, coexposure induces a greater effect with a unique transcriptomic profiles of genes involved in the ETC; this is highlighted by the number of ETC genes differentially expressed in $\mathrm{CB}(0), \mathrm{O}_{3}$ (2), and co-exposure (35). Although both the $\mathrm{O}_{3}$ and $\mathrm{CB}+\mathrm{O}_{3}$ groups show a reduction in Complex I and IV activity, the co-exposure group uniquely modifies ATP Synthase function. Further, a disconnect exists between mRNA expression and mitochondrial protein levels for ATP Synthase following coexposure, represented by increased mRNA expression of ATP5F1, with reductions in actual protein content. Contrary to this, we found significant increases in the levels of ATP5F1 in IHC. This suggests that the reduced activity of ATP Synthase is likely due to both the decreased efficiency of electrons travelling through the ETC, identified through electron flow, as well as a disruption in import/integration of subunits for ATP Synthase, such as ATP5F1 into the mitochondria. Observation of such defect in mitochondrial import of proteins is not surprising as we previously demonstrated such defects in mitochondrial protein import in diabetic heart [54, 79]. We only evaluated ATP5F1 levels and did not analyze the entire ATP synthase complex, it is possible that other protein constituents of the ATP synthase complex were also affected by the co-exposure. Using broad scale proteomic methodologies, our collaborators have observed changes in multiple protein constituents in electron transport chain complexes following pathological insults, which likely, in aggregate precipitate functional compromise in the complex $[53,54,80]$. It should be noted that in our study, ATP levels and ATP synthase activity were also decreased in case of the co-exposure, suggesting that the loss of ATP5F1, may be partly responsible for the functional changes observed.

In order to clarify a potential link between the inflammatory response and mitochondrial function, we studied NADPH oxidase system alterations. NADPH oxidase system is among the best described pathways connecting inflammatory response and mitochondrial dysfunction through reactive oxygen species (ROS) production [81-85]. Real time PCR has recently been recommended as the method of choice for initial screening of NADPH pathway [86]. Our results clearly indicated increased mRNA expression of Nox2 as well as Duox2 subunits as well as adaptor proteins $\mathrm{P} 40^{\text {phox }}$, and $\mathrm{P} 47^{\text {phox }}{ }^{\text {. While }}$ Nox2 is a well-known for its expression in function in phagocytes, Duox2 is highly expressed by the epithelial cell in the lungs $[81,87,88]$. This increase further confirm exposure induced ROS production pathway activation goes beyond the infiltrating leukocytes and point towards a tissue level biochemical/pathologic alteration. Moreover, our histology data indicate an aberrant repair process with hyperplastic and regenerating epithelia which have known/well established mitochondria activity change implications [89]. These clearly point towards a tissue level change rather than just infiltration of leukocytes. These findings of increased ROS production are in line with our recently published immuno spin-trapping data which also confirmed presence of oxidants in macrophages as well as epithelial cells in the lungs after similar exposure ([90]. NOX derived ROS play an important role in regulating NLRP3 inflammasome (reviewed in [81]). We demonstrate an increase in IL- $1 \beta$ levels (Fig. 3E) which is a typical NLRP3 downstream cytokine. Increase $\mathrm{H}_{2} \mathrm{O}_{2}$ levels after single exposure point towards oxidant generation being an early event followed by mitochondrial damage. Taken together with our recently published results demonstrating a key role of oxidants in lung inflammation and lung function decline through production of thymic stromal lymphopoietin further consolidates the key role of enhanced ROS production in inflammatory responses after $\mathrm{CB}+\mathrm{O}_{3}$ co-exposure ([90]. It is plausible to hypothesize that this ROS production led to/amplify the mitochondrial damage response that was significantly greater after multiple exposures. It is important to note that mitochondrial damage is known to play a critical role in the pathogenesis of multiple pulmonary disorders which also are exacerbated by the air pollution exposures [91-96].

\section{Conclusions}

In the current study we evaluated the impact of $\mathrm{CB}$ and $\mathrm{O}_{3}$ co-exposure on the transcriptomic profile of the lungs. By implementing an acute (one day) and sustained (four consecutive days) exposure model, we effectively captured the progressive adaptions that $\mathrm{CB}, \mathrm{O}_{3}$, and coexposure produce in the lungs. Co-exposure provokes an exaggerated response that cannot be accounted for based on the individual profiles of the toxicants present. This unique response is best characterized by decreased 
mitochondrial ETC function, specifically at ATP Synthase. Future assessments will be critical in accurately characterizing the longitudinal effects of particulate matter and ozone on mitochondrial function in the lungs.

\section{Supplementary Information}

The online version contains supplementary material available at https://doi. org/10.1186/s12989-021-00437-8.

\section{Additional file 1. Raw data values used for generation of heat maps} for real time PCR, ELISA, and primer sequences.

\section{Additional file 2. Differential expression analyses.}

Additional file 3. Fig. S1: Bronchoalveolar lavage total cells and macrophages depicting increased potency of $\mathrm{CB}+\mathrm{O}_{3}$ co-exposure to induce lung inflammation after (A) 1 Day exposure $(n=5-7)$ and $(\mathbf{B}) 4$ Days exposure $(n=5-7)$ compared to filtered air, $C B\left(10 \mathrm{mg} / \mathrm{m}^{3}\right)$ and $\mathrm{O} 3$ (2 ppm). Data are presented as mean \pm SEM of $n=5-7$ mice per group and analyzed by two-way analysis of variance (ANOVA) followed by Tukey's post hoc test. ${ }^{*} P \leq 0.05,{ }^{*} P \leq 0.01,{ }^{* * *} P \leq 0.001$

Additional file 4. Fig. S2: Bioinformatic analysis of the lung transcriptome in $\mathrm{CB}, \mathrm{O}_{3}$, and co-exposed mice. (A) Principal component analysis (PCA) illustrating the distribution of individual samples in each group. (B) Differential gene expression matrix, with the number and color correlating to the genes significantly altered between comparisons. (C) Heatmap of the top 500 differentially regulated genes between all groups. The heatmap displays the top differentially expressed genes by Padj-value, stratified by the Co-Exposure group on Day 4. We chose 500 as a conservative number to help capture more differentially expressed genes in other groups (ranging from 200 to $\sim 4000$ differentially expressed genes, depending on group), while allowing for the graphic to still be interpretable. Day $1(n=4$, each group) and Day $4(n=3$, each group). Sham mice were exposed to filtered air. Number following the exposure condition denotes number of times (either one or four) animals were exposed. Animals were euthanized and analyzed $24 \mathrm{~h}$ post single or four exposures. Sham $-1=$ filtered air exposed for 1 day, Sham $-4=$ filtered air exposed for 4 days, $C B$ $1=$ carbon black exposed $\left(10 \mathrm{mg} / \mathrm{m}^{3}\right)$ for a duration of $(3 \mathrm{~h})$ for 1 day, CB $-4=$ carbon black exposed $\left(10 \mathrm{mg} / \mathrm{m}^{3}\right)$ for a duration of $(3 \mathrm{~h})$ for 4 days, $\mathrm{O}_{3}-1=$ ground level ozone exposed ( $2 \mathrm{ppm}$ ) for a duration of ( $3 \mathrm{~h}$ ) for 1 day, $\mathrm{O}_{3}-4=$ ground level ozone exposed (2 ppm) for a duration of ( $3 \mathrm{~h}$ ) for 4 days, $\mathrm{CB}-\mathrm{O}_{3}-1=$ carbon black $\left(10 \mathrm{mg} / \mathrm{m}^{3}\right)$ and ground level ozone exposed ( $2 \mathrm{ppm}$ ) for a duration of ( $3 \mathrm{~h}$ ) for 1 day, $\mathrm{CB}-\mathrm{O}_{3}-4=$ carbon black $\left(10 \mathrm{mg} / \mathrm{m}^{3}\right)$ and ground level ozone exposed (2 ppm) for a duration of ( 3 h) for 4 days

Additional file 5. Fig. S3: Volcano plots depicting changes in gene expression by comparison to the Sham exposure group. Genes depicted as green are not considered statistically different. Day 1 ( $n=4$, each group) and Day 4 ( $n=3$, each group). Sham $-1=$ filtered air exposed for 1 day, Sham $-4=$ filtered air exposed for 4 days, $C B-1=$ carbon black exposed $\left(10 \mathrm{mg} / \mathrm{m}^{3}\right)$ for a duration of ( $\left.3 \mathrm{~h}\right)$ for 1 day, $\mathrm{CB}-4=$ carbon black exposed $\left(10 \mathrm{mg} / \mathrm{m}^{3}\right)$ for a duration of $(3 \mathrm{~h})$ for 4 days, $\mathrm{O}_{3}-1=$ ground level ozone exposed ( $2 \mathrm{ppm}$ ) for a duration of ( $3 \mathrm{~h}$ ) for 1 day, $\mathrm{O}_{3}-4=$ ground level ozone exposed ( 2 ppm) for a duration of ( $3 \mathrm{~h}$ ) for 4 days, $\mathrm{CB}_{-} \mathrm{O}_{3}-$ 1 = carbon black $\left(10 \mathrm{mg} / \mathrm{m}^{3}\right)$ and ground level ozone exposed $(2 \mathrm{ppm})$ for a duration of $(3 \mathrm{~h})$ for 1 day, $\mathrm{CB}-\mathrm{O}_{3}-4=$ carbon black $\left(10 \mathrm{mg} / \mathrm{m}^{3}\right)$ and ground level ozone exposed (2 ppm) for a duration of ( $3 \mathrm{~h}$ ) for 4 days, $\mathrm{P}=$ genes with $-\log _{10} P$-adjusted value of $>1.3$ and $\log _{2}$ fold change $<1$, $P \& \log _{2} F C=$ genes with $-\log _{10} P$-adjusted value of $>1.3$ and $\log _{2}$ fold change $>1$.

Additional file 6. Fig. S4: Differential gene expression unique to the co-exposure groups. Venn diagrams for (A) single and (B) four exposures. The unique differentially expressed genes were placed in a volcano plot to highlight the expression profile for $(\mathbf{C})$ single and (D) four exposures. Day 1 ( $n=4$, each group) and Day 4 ( $n=3$, each group). Sham mice were exposed to filtered air. Number following the exposure condition denotes number of times (either one or four) animals were exposed.
Animals were euthanized and analyzed $24 \mathrm{~h}$ post single or four exposures. $P=$ genes with $-\log _{10} P$-adjusted value of $>1.3$ and $\log _{2}$ fold change $<1$, $P \& \log _{2} F C=$ genes with $-\log _{10} P$-adjusted value of $>1.3$ and $\log _{2}$ fold change $>1, D E=$ differentially expressed genes.

Additional file 7. Fig. S5: Common ontology pathways between all groups. (A) 6-way Venn diagram illustrating the similar/dissimilar gene pathways between groups. (B) The three shared pathways between all groups are outlined with a few representative genes selected in the up regulated and down regulated columns. Sham $-1=$ filtered air exposed for 1 day, Sham $-4=$ filtered air exposed for 4 days, $C B-1=$ carbon black exposed $\left(10 \mathrm{mg} / \mathrm{m}^{3}\right)$ for a duration of $(3 \mathrm{~h})$ for 1 day, $\mathrm{CB}-4=$ carbon black exposed $\left(10 \mathrm{mg} / \mathrm{m}^{3}\right)$ for a duration of $(3 \mathrm{~h})$ for 4 days, $\mathrm{O}_{3}-1=$ ground level ozone exposed ( $2 \mathrm{ppm}$ ) for a duration of $(3 \mathrm{~h})$ for 1 day, $\mathrm{O}_{3}$ $4=$ ground level ozone exposed ( $2 \mathrm{ppm}$ ) for a duration of ( $3 \mathrm{~h}$ ) for 4 days, CB- ${ }_{3}-1=$ carbon black $\left(10 \mathrm{mg} / \mathrm{m}^{3}\right)$ and ground level ozone exposed ( $2 \mathrm{ppm}$ ) for a duration of ( $3 \mathrm{~h}$ ) for 1 day, $\mathrm{CB}-\mathrm{O}_{3}-4=$ carbon black (10 mg/ $\mathrm{m}^{3}$ ) and ground level ozone exposed (2 ppm) for a duration of (3 h) for 4 days, ID = ID of the enriched term for KEGG ontology, Term Description $=$ description of the enriched term and identified pathway, Fold Enrichment = fold enrichment value for the enriched term (Calculated using ONLY the input genes), Up Regulated=genes that are increased in expression in the pathway, Down Regulated=genes that are decreased in expression in the pathway.

Additional file 8. Fig. S6: Examining mitochondrial protein content (A) Western blot analysis for a protein subunit of mitochondrial ETC complex I (NDUFA9), complex II (SDHA), complex III (UQCRC2), complex IV (COXIV) and complex V/ATP Synthase (ATP5A), normalized to VDAC expression. Data are presented as mean \pm SEM of $n=3-4$ mice per group and analyzed by two-way analysis of variance (ANOVA) followed by Tukey's post hoc test. ${ }^{*} P \leq 0.05,{ }^{*} P \leq 0.01,{ }^{* * *} P \leq 0.001$. Sham $-4=$ filtered air exposed for 4 days, $C B-4=10 \mathrm{mg} / \mathrm{m}^{3} \mathrm{CB}$ exposure for $3 \mathrm{~h}$ repeated four times (24 h apart), $\mathrm{O}_{3}-4=2 \mathrm{ppm} \mathrm{O}_{3}$ exposure for $3 \mathrm{~h}$ repeated four times $(24 \mathrm{~h}$ apart), $\mathrm{CB}+\mathrm{O}_{3}-4=10 \mathrm{mg} / \mathrm{m}^{3} \mathrm{CB}$ and $2 \mathrm{ppm} \mathrm{O}_{3}$ inhalation co-exposure for $3 \mathrm{~h}$ repeated four times ( $24 \mathrm{~h}$ apart), Cl=complex I, CII = complex II, $\mathrm{CIII}=$ complex III, CIV = complex IV, CV = complex V.

Additional file 9. Fig. S7: Light photomicrographs of centriacinar regions in the lungs of mice exposed for 4 days to A) filtered air (controls), B) carbon black, C) ozone, and D) carbon black and ozone. Airway epithelium (e) lining terminal bronchioles (tb), alveolar type II epithelial cells and associated alveolar macrophages in proximal alveolar ducts (ad) are immunohistochemically stained for ATP5F1 in C) and D). Stippled arrows, carbon black particles. Tissues were counterstained with hematoxylin.

\section{Acknowledgements}

Special thanks for excellent technical assistance by Zirong Xie, Sherri A. Friend, Ryan Percifield, Kevin Engels, and Md. Habibul Mazumder.

\section{Authors' contributions}

QAH: Methodology, Investigation, Formal Analysis, Visualization, Writing original draft. NM: Methodology, Investigation, Formal Analysis, Visualization, Writing original draft. WTG: Methodology, Investigation, Formal Analysis, Software, Visualization, Writing original draft. AK: Methodology, Investigation, Formal Analysis, Visualization, Writing original draft. MVP: Investigation, Formal Analysis. JH: Investigation, Formal Analysis, Writing original draft. VC: Conceptualization, Writing original draft. JMH: Investigation, Formal Analysis, Visualization, Writing original draft. Supervision. SH: Conceptualization, Methodology, Investigation, Formal Analysis, Visualization, Writing original draft, Supervision, Project Administration, Acquisition of Funding. All authors read and approved the final manuscript.

\section{Funding}

This work was supported by: NIH/NIEHS R01 ES031253 (SH), NIGHMS U54GM104942 (SH), NHLBI R01 HL128485 (JMH), AHA-17PRE33660333 (QAH), AHA-20PRE35080170 (AK), WVU Genomics Core Facility support by CTSI Grant [U54GM104942], and the Community Foundation for the Ohio Valley Whipkey Trust. 


\section{Availability of data and materials}

All sequencing data and code have been made freely available: (1) Coding for bioinformatics is provided here: https://github.com/qahathaway/Co-Exposure; (2) Raw and processed transcriptomic reads have been added here: https:// www.ncbi.nlm.nih.gov/geo/query/acc.cgi?acc=GSE161538; (3) Raw data values used for generation of heat maps for Real time PCR/ ELISA, and prime sequences are provided in Additional file 1.(4) Differential expression analysis is provided in Additional file 2; (5) Other data sets analyzed in this study are available from corresponding author on reasonable request.

\section{Declarations}

\section{Ethics approval and consent to participate}

Not applicable.

\section{Consent for publication}

Not applicable.

\section{Competing interests}

Authors have no relevant financial or non-financial interests to disclose.

\section{Author details}

${ }^{1}$ Division of Exercise Physiology, West Virginia University School of Medicine, Morgantown, WV, USA. ${ }^{2}$ Mitochondria, Metabolism and Bioenergetics Working Group, West Virginia University School of Medicine, Morgantown, WV, USA. ${ }^{3}$ Center for Inhalation Toxicology (iTOX), West Virginia University School of Medicine, Morgantown, WV, USA. ${ }^{4}$ Department of Physiology and Pharmacology, West Virginia University School of Medicine, 64 Medical Center Drive, PO Box 9229, Morgantown, WV 26506-9229, USA. ${ }^{5}$ West Virginia University School of Pharmacy, Morgantown, WV, USA. ${ }^{6}$ Department of Pathobiology and Diagnostic Investigation, College of Veterinary Medicine, Michigan State University, East Lansing, MI, USA.

Received: 16 April 2021 Accepted: 26 November 2021

Published online: 15 December 2021

\section{References}

1. Organization WH. World Health Statistics 2016: Monitoring health for the SDGs https://www.who.int/gho/publications/world_health_statistics/ 2016/Annex B/en/. Accessed 14 Jan 2019. 2016.

2. Cohen AJ, Brauer M, Burnett R, Anderson HR, Frostad J, Estep K, et al. Estimates and 25-year trends of the global burden of disease attributable to ambient air pollution: an analysis of data from the Global Burden of Diseases Study 2015. Lancet. 2017;389(10082):1907-18. https://doi.org/ 10.1016/S0140-6736(17)30505-6

3. Gbdcrd C. Global, regional, and national deaths, prevalence, disabilityadjusted life years, and years lived with disability for chronic obstructive pulmonary disease and asthma, 1990-2015: a systematic analysis for the Global Burden of Disease Study 2015. Lancet Respir Med. 2017;5(9):691706. https://doi.org/10.1016/S2213-2600(17)30293-X

4. Gbdrfc C. Global, regional, and national comparative risk assessment of 79 behavioural, environmental and occupational, and metabolic risks or clusters of risks, 1990-2015: a systematic analysis for the Global Burden of Disease Study 2015. Lancet. 2016;388(10053):1659-724. https://doi.org/ 10.1016/S0140-6736(16)31679-8.

5. Dockery DW, Pope CA III, Xu X, Spengler JD, Ware JH, Fay ME, et al. An association between air pollution and mortality in six U.S. cities. N Engl Med. 1993;329(24):1753-9. https://doi.org/10.1056/NEJM19931209329 2401.

6. Rhee J, Dominici F, Zanobetti A, Schwartz J, Wang J, Di Q, Christiani DC. The imapct of long-term exposure to PM2.5 and ozone on the risk of Acute Respiratory Distress Syndrome (ARDS) for elderly. Am J Respir Crit Care Med. 2018;197:A6192.

7. Li X, Cao X, Guo M, Xie M, Liu X. Trends and risk factors of mortality and disability adjusted life years for chronic respiratory diseases from 1990 to 2017: systematic analysis for the Global Burden of Disease Study 2017. BMJ. 2020;368: m234. https://doi.org/10.1136/bmj.m234.
8. Scannell C, Chen L, Aris RM, Tager I, Christian D, Ferrando R, et al. Greater ozone-induced inflammatory responses in subjects with asthma. Am J Respir Crit Care Med. 1996;154(1):24-9. https://doi.org/10.1164/ajrccm. 154.1.8680687

9. Farhat $\mathrm{SCL}$, Almeida MB, Silva-Filho L, Farhat J, Rodrigues JC, Braga ALF Ozone is associated with an increased risk of respiratory exacerbations in patients with cystic fibrosis. Chest. 2013;144(4):1186-92. https://doi.org/ 10.1378/chest.12-2414.

10. Halonen JI, Lanki T, Tiittanen P, Niemi JV, Loh M, Pekkanen J. Ozone and cause-specific cardiorespiratory morbidity and mortality. J Epidemiol Community Health. 2010;64(9):814-20. https://doi.org/10.1136/jech.2009. 087106.

11. Wilson A, Reich BJ, Nolte CG, Spero TL, Hubbell B, Rappold AG. Climate change impacts on projections of excess mortality at 2030 using spatially varying ozone-temperature risk surfaces. J Expo Sci Environ Epidemiol. 2017;27(1):118-24. https://doi.org/10.1038/jes.2016.14.

12. Orru H, Andersson C, Ebi KL, Langner J, Astrom C, Forsberg B. Impact of climate change on ozone-related mortality and morbidity in Europe. Eur Respir J. 2013;41(2):285-94. https://doi.org/10.1183/09031936.00210411.

13. Rattanasom N, Saowapark T, Deeprasertkul C. Reinforcement of natural rubber with silica/carbon black hybrid filler. Polym Test. 2007;26(3):369-77.

14. ICBA. Carbon black user's guide. International Carbon Black Association. 2016. http://www.carbonblack.org/images/docs/2016-ICBA-CarbonBlack-User-Guide.pdf.

15. IARC. Monographs on the evaluation of carcinogenic risks to humans Carbon black, Titanium dioxide and Talc. https://publications.iarc.fr/ Book-And-Report-Series/larc-Monographs-On-The-IdentificationOf-Carcinogenic-Hazards-To-Humans/Carbon-Black-Titanium-Dioxi de-And-Talc-2010.

16. Madden MC, Richards JH, Dailey LA, Hatch GE, Ghio AJ. Effect of ozone on diesel exhaust particle toxicity in rat lung. Toxicol Appl Pharmacol. 2000;168(2):140-8. https://doi.org/10.1006/taap.2000.9024.

17. Cassee FR, Boere AJ, Bos J, Fokkens PH, Dormans JA, van Loveren H. Effects of diesel exhaust enriched concentrated PM2.5 in ozone preexposed or monocrotaline-treated rats. Inhal Toxicol. 2002;14(7):721-43. https://doi.org/10.1080/08958370290084601.

18. Kafoury RM, Kelley J. Ozone enhances diesel exhaust particles (DEP)induced interleukin-8 (IL-8) gene expression in human airway epithelial cells through activation of nuclear factors-kappaB (NF-kappaB) and IL-6 (NF-IL6). Int J Environ Res Public Health. 2005;2(3-4):403-10.

19. Hamade AK, Rabold R, Tankersley CG. Adverse cardiovascular effects with acute particulate matter and ozone exposures: interstrain variation in mice. Environ Health Perspect. 2008;1 16(8):1033-9. https://doi.org/10. 1289/ehp.10689

20. Ghio AJ, Gonzalez DH, Paulson SE, Soukup JM, Dailey LA, Madden $M C$, et al. Ozone reacts with carbon black to produce a fulvic acidlike substance and increase an inflammatory effect. Toxicol Pathol. 2020:48(7):887-98. https://doi.org/10.1177/0192623320961017.

21. Hamade AK, Misra V, Rabold R, Tankersley CG. Age-related changes in cardiac and respiratory adaptation to acute ozone and carbon black exposures: interstrain variation in mice. Inhal Toxicol. 2010;22(Suppl 2):84-94. https://doi.org/10.3109/08958378.2010.503974.

22. Wagner JG, Allen K, Yang HY, Nan B, Morishita M, Mukherjee B, et al. Cardiovascular depression in rats exposed to inhaled particulate matter and ozone: effects of diet-induced metabolic syndrome. Environ Health Perspect. 2014;122(1):27-33. https://doi.org/10.1289/ehp.1307085.

23. Hamade AK, Tankersley CG. Interstrain variation in cardiac and respiratory adaptation to repeated ozone and particulate matter exposures. Am J Physiol Regul Integr Comp Physiol. 2009;296(4):R1202-15. https://doi.org/ 10.1152/ajpregu.90808.2008.

24. Wong EM, Walby WF, Wilson DW, Tablin F, Schelegle ES. Ultrafine particulate matter combined with ozone exacerbates lung injury in mature adult rats with cardiovascular disease. Toxicol Sci. 2018;163(1):140-51. https:// doi.org/10.1093/toxsci/kfy018.

25. Kunovac A, Hathaway QA, Pinti MV, Taylor AD, Hollander JM. Cardiovascular adaptations to particle inhalation exposure: molecular mechanisms of the toxicology. Am J Physiol Heart Circ Physiol. 2020;319(2):H282-305. https://doi.org/10.1152/ajpheart.00026.2020.

26. Byun J, Song B, Lee K, Kim B, Hwang HW, OK MR, et al. Identification of urban particulate matter-induced disruption of human respiratory 
mucosa integrity using whole transcriptome analysis and organ-on-a chip. J Biol Eng. 2019;13:88. https://doi.org/10.1 186/s13036-019-0219-7.

27. Wang H, Shen X, Liu J, Wu C, Gao J, Zhang Z, et al. The effect of exposure time and concentration of airborne PM2.5 on lung injury in mice: a transcriptome analysis. Redox Biol. 2019;26:101264. https://doi.org/10.1016/j. redox.2019.101264.

28. Gabehart K, Correll KA, Yang J, Collins ML, Loader JE, Leach S, et al. Transcriptome profiling of the newborn mouse lung response to acute ozone exposure. Toxicol Sci. 2014;138(1):175-90. https://doi.org/10.1093/toxsci/ kft276.

29. Tovar A, Smith GJ, Thomas JM, Crouse WL, Harkema JR, Kelada SNP. Transcriptional profiling of the murine airway response to acute ozone exposure. Toxicol Sci. 2020;173(1):114-30. https://doi.org/10.1093/toxsci/ kfz219.

30. Haghani A, Johnson RG, Woodward NC, Feinberg Jl, Lewis K, Ladd-Acosta $C$, et al. Adult mouse hippocampal transcriptome changes associated with long-term behavioral and metabolic effects of gestational air pollution toxicity. Transl Psychiatry. 2020;10(1):218. https://doi.org/10.1038/ s41398-020-00907-1.

31. Jackson P, Hougaard KS, Vogel U, Wu D, Casavant L, Williams A, et al. Exposure of pregnant mice to carbon black by intratracheal instillation: toxicogenomic effects in dams and offspring. Mutat Res. 2012;745(12):73-83. https://doi.org/10.1016/j.mrgentox.2011.09.018.

32. Pirela SV, Martin J, Bello D, Demokritou P. Nanoparticle exposures from nano-enabled toner-based printing equipment and human health: state of science and future research needs. Crit Rev Toxicol. 2017;47(8):678704. https://doi.org/10.1080/10408444.2017.1318354

33. Singh D, Marrocco A, Wohlleben W, Park HR, Diwadkar AR, Himes BE, et al. Release of particulate matter from nano-enabled building materials (NEBMs) across their lifecycle: Potential occupational health and safety implications. J Hazard Mater. 2021;422: 126771. https://doi.org/10.1016/j. jhazmat.2021.126771.

34. Peebles BC, Dutta PK, Waldman WJ, Villamena FA, Nash K, Severance $M$, et al. Physicochemical and toxicological properties of commercial carbon blacks modified by reaction with ozone. Environ Sci Technol. 2011:45(24):10668-75. https://doi.org/10.1021/es202984t.

35. Hatch GE, Slade R, Harris LP, McDonnell WF, Devlin RB, Koren HS, et al. Ozone dose and effect in humans and rats. A comparison using oxygen-18 labeling and bronchoalveolar lavage. Am J Respir Crit Care Med. 1994;150(3):676-83. https://doi.org/10.1164/ajrccm.150.3.8087337.

36. Hatch GE, McKee J, Brown J, McDonnell W, Seal E, Soukup J, et al. Biomarkers of dose and effect of inhaled ozone in resting versus exercising human subjects: comparison with resting rats. Biomark Insights. 2013;8:53-67. https://doi.org/10.4137/BMI.S11102.

37. Michaudel C, Fauconnier L, Jule Y, Ryffel B. Functional and morphological differences of the lung upon acute and chronic ozone exposure in mice. Sci Rep. 2018:8(1):10611. https://doi.org/10.1038/s41598-018-28261-9.

38. Michaudel C, Mackowiak C, Maillet I, Fauconnier L, Akdis CA, Sokolowska $M$, et al. Ozone exposure induces respiratory barrier biphasic injury and inflammation controlled by IL-33. J Allergy Clin Immunol. 2018;142(3):942-58. https://doi.org/10.1016/j.jaci.2017.11.044

39. Michaudel C, Maillet I, Fauconnier L, Quesniaux V, Chung KF, Wiegman $C$, et al. Interleukin-1 alpha mediates ozone-induced myeloid differentiation factor-88-dependent epithelial tissue injury and inflammation. Front Immunol. 2018:9:916. https://doi.org/10.3389/fimmu.2018.00916.

40. Elder A, Gelein R, Finkelstein JN, Driscoll KE, Harkema J, Oberdorster G. Effects of subchronically inhaled carbon black in three species. I. Retention kinetics, lung inflammation, and histopathology. Toxicol Sci. 2005;88(2):614-29. https://doi.org/10.1093/toxsci/kfi327.

41. Livak KJ, Schmittgen TD. Analysis of relative gene expression data using real-time quantitative PCR and the 2(-Delta Delta C(T)) Method. Methods. 2001;25(4):402-8. https://doi.org/10.1006/meth.2001.1262.

42. Patro R, Duggal G, Love MI, Irizarry RA, Kingsford C. Salmon provides fast and bias-aware quantification of transcript expression. Nat Methods. 2017;14(4):417-9. https://doi.org/10.1038/nmeth.4197.

43. Srivastava A, Malik L, Sarkar H, Zakeri M, Almodaresi F, Soneson C, et al. Alignment and mapping methodology influence transcript abundance estimation. Genome Biol. 2020;21 (1):239. https://doi.org/10.1186/ s13059-020-02151-8.

44. Love MI, Soneson C, Hickey PF, Johnson LK, Pierce NT, Shepherd L, et al. Tximeta: Reference sequence checksums for provenance identification in RNA-seq. PLoS Comput Biol. 2020;16(2): e1007664. https://doi.org/10. 1371/journal.pcbi.1007664.

45. Love MI, Huber W, Anders S. Moderated estimation of fold change and dispersion for RNA-seq data with DESeq2. Genome Biol. 2014;15(12):550. https://doi.org/10.1186/s13059-014-0550-8.

46. Wickham H. ggplot2: Elegant Graphics for Data Analysis. Use R. 2009:1212. https://doi.org/10.1007/978-0-387-98141-3.

47. Ritchie ME, Phipson B, Wu D, Hu Y, Law CW, Shi W, et al. limma powers differential expression analyses for RNA-sequencing and microarray studies. Nucleic Acids Res. 2015;43(7): e47. https://doi.org/10.1093/nar/gkv007.

48. McDermaid A, Monier B, Zhao J, Liu B, Ma Q. Interpretation of differential gene expression results of RNA-seq data: review and integration. Brief Bioinform. 2018. https://doi.org/10.1093/bib/bby067.

49. Blighe K, Rana S, Lewis S. EnhancedVolcano: publication-ready volcano plots with enhanced colouring and labeling. 2018. https://github.com/ kevinblighe.

50. Heberle H, Meirelles GV, da Silva FR, Telles GP, Minghim R. InteractiVenn: a web-based tool for the analysis of sets through Venn diagrams. BMC Bioinform. 2015;16:169. https://doi.org/10.1186/s12859-015-0611-3.

51. Ulgen E, Ozisik O, Sezerman OU. pathfindR: an $R$ package for comprehensive identification of enriched pathways in omics data through active subnetworks. Front Genet. 2019;10:858. https://doi.org/10.3389/fgene. 2019.00858.

52. Carlson M: KEGG.db: a set of annotation maps for KEGG. R package version 3.2.32016

53. Baseler WA, Dabkowski ER, Williamson CL, Croston TL, Thapa D, Powell MJ, et al. Proteomic alterations of distinct mitochondrial subpopulations in the type 1 diabetic heart: contribution of protein import dysfunction. Am J Physiol Regul Integr Comp Physiol. 2011;300(2):R186-200. https://doi. org/10.1152/ajpregu.00423.2010.

54. Baseler WA, Dabkowski ER, Jagannathan R, Thapa D, Nichols CE, Shepherd $\mathrm{DL}$, et al. Reversal of mitochondrial proteomic loss in Type 1 diabetic heart with overexpression of phospholipid hydroperoxide glutathione peroxidase. Am J Physiol Regul Integr Comp Physiol. 2013;304(7):R55365. https://doi.org/10.1152/ajpregu.00249.2012.

55. Hathaway QA, Roth SM, Pinti MV, Sprando DC, Kunovac A, Durr AJ, et al. Machine-learning to stratify diabetic patients using novel cardiac biomarkers and integrative genomics. Cardiovasc Diabetol. 2019;18(1):78. https://doi.org/10.1186/s12933-019-0879-0.

56. Bradford MM. A rapid and sensitive method for the quantitation of microgram quantities of protein utilizing the principle of protein-dye binding. Anal Biochem. 1976:72:248-54.

57. Thapa D, Nichols CE, Lewis SE, Shepherd DL, Jagannathan R, Croston TL, et al. Transgenic overexpression of mitofilin attenuates diabetes mellitusassociated cardiac and mitochondria dysfunction. J Mol Cell Cardiol. 2015;79:212-23. https://doi.org/10.1016/j.yjmcc.2014.11.008.

58. Nichols CE, Shepherd DL, Knuckles TL, Thapa D, Stricker JC, Stapleton PA, et al. Cardiac and mitochondrial dysfunction following acute pulmonary exposure to mountaintop removal mining particulate matter. Am J Physiol Heart Circ Physiol. 2015;309(12):H2017-30. https://doi.org/10. 1152/ajpheart.00353.2015.

59. Hathaway QA, Durr AJ, Shepherd DL, Pinti MV, Brandebura AN, Nichols $C E$, et al. miRNA-378a as a key regulator of cardiovascular health following engineered nanomaterial inhalation exposure. Nanotoxicology. 2019:13(5):644-63. https://doi.org/10.1080/17435390.2019.1570372.

60. Hathaway QA, Nichols CE, Shepherd DL, Stapleton PA, McLaughlin SL, Stricker JC, et al. Maternal-engineered nanomaterial exposure disrupts progeny cardiac function and bioenergetics. Am J Physiol Heart Circ Physiol. 2017;312(3):H446-58. https://doi.org/10.1152/ajpheart.00634. 2016.

61. Rogers GW, Brand MD, Petrosyan S, Ashok D, Elorza AA, Ferrick DA, et al. High throughput microplate respiratory measurements using minimal quantities of isolated mitochondria. PLoS ONE. 2011;6(7): e21746. https:// doi.org/10.1371/journal.pone.0021746.

62. Kramer A, Green J, Pollard J Jr, Tugendreich S. Causal analysis approaches in ingenuity pathway analysis. Bioinformatics. 2014;30(4):523-30. https:// doi.org/10.1093/bioinformatics/btt703.

63. Kunovac A, Hathaway QA, Pinti MV, Goldsmith WT, Durr AJ, Fink GK, et al. ROS promote epigenetic remodeling and cardiac dysfunction in offspring following maternal engineered nanomaterial (ENM) exposure. Part Fibre Toxicol. 2019;16(1):24. https://doi.org/10.1186/s12989-019-0310-8. 
64. Malik D, Kaul D. Human cellular mitochondrial remodelling is governed by miR-2909 RNomics. PLoS ONE. 2018;13(9): e0203614. https://doi.org/ 10.1371/journal.pone.0203614.

65. Long CM, Nascarella MA, Valberg PA. Carbon black vs. black carbon and other airborne materials containing elemental carbon: physical and chemical distinctions. Environ Pollut. 2013;181:271-86. https://doi.org/10. 1016/j.envpol.2013.06.009.

66. Wagner JG, Barkauskas CE, Vose A, Lewandowski RP, Harkema JR, Tighe RM. Repetitive ozone exposures and evaluation of pulmonary inflammation and remodeling in diabetic mouse strains. Environ Health Perspect. 2020;128(11): 117009. https://doi.org/10.1289/EHP7255.

67. Hussain S, Johnson CG, Sciurba J, Meng X, Stober VP, Liu C, et al. TLR5 participates in the TLR4 receptor complex and promotes MyD88-dependent signaling in environmental lung injury. Elife. 2020. https://doi.org/10. 7554/eLife.50458

68. Fievez L, Kirschvink N, Dogne S, Jaspar F, Merville MP, Bours V, et al. Impaired accumulation of granulocytes in the lung during ozone adaptation. Free Radic Biol Med. 2001;31(5):633-41. https://doi.org/10.1016/ s0891-5849(01)00621-9.

69. Chimenti L, Morici G, Paterno A, Bonanno A, Vultaggio M, Bellia V, et al. Environmental conditions, air pollutants, and airway cells in runners: a longitudinal field study. J Sports Sci. 2009;27(9):925-35. https://doi.org/ 10.1080/02640410902946493.

70. Lundborg M, Johard U, Lastbom L, Gerde P, Camner P. Human alveolar macrophage phagocytic function is impaired by aggregates of ultrafine carbon particles. Environ Res. 2001;86(3):244-53. https://doi.org/10.1006/ enrs.2001.4269.

71. Broeckaert F, Arsalane K, Hermans C, Bergamaschi E, Brustolin A, Mutti A, et al. Serum clara cell protein: a sensitive biomarker of increased lung epithelium permeability caused by ambient ozone. Environ Health Perspect. 2000;108(6):533-7. https://doi.org/10.1289/ehp.00108533.

72. Linnoila RI, Szabo E, DeMayo F, Witschi H, Sabourin C, Malkinson A. The role of CC10 in pulmonary carcinogenesis: from a marker to tumor suppression. Ann N Y Acad Sci. 2000;923:249-67. https://doi.org/10.1111/j. 1749-6632.2000.tb05534.x.

73. Nureki SI, Tomer Y, Venosa A, Katzen J, Russo SJ, Jamil S, et al. Expression of mutant Sftpc in murine alveolar epithelia drives spontaneous lung fibrosis. J Clin Invest. 2018;128(9):4008-24. https://doi.org/10.1172/JCI99 287.

74. Provost EB, Chaumont A, Kicinski M, Cox B, Fierens F, Bernard A, et al. Serum levels of club cell secretory protein (Clara) and short- and longterm exposure to particulate air pollution in adolescents. Environ Int. 2014;68:66-70. https://doi.org/10.1016/j.envint.2014.03.011.

75. Shen Y, Wu L, Qin D, Xia Y, Zhou Z, Zhang X, et al. Carbon black suppresses the osteogenesis of mesenchymal stem cells: the role of mitochondria. Part Fibre Toxicol. 2018;15(1):16. https://doi.org/10.1186/ s12989-018-0253-5.

76. Gao X, Xu H, Shang J, Yuan L, Zhang Y, Wang L, et al. Ozonized carbon black induces mitochondrial dysfunction and DNA damage. Environ Toxicol. 2017;32(3):944-55. https://doi.org/10.1002/tox.22295.

77. Chuang GC, Yang Z, Westbrook DG, Pompilius M, Ballinger CA, White $C R$, et al. Pulmonary ozone exposure induces vascular dysfunction, mitochondrial damage, and atherogenesis. Am J Physiol Lung Cell Mol Physiol. 2009;297(2):L209-16. https://doi.org/10.1152/ajplung.00102. 2009.

78. Valdez MC, Freeborn D, Valdez JM, Johnstone AFM, Snow SJ, Tennant $\mathrm{AH}$, et al. Mitochondrial bioenergetics in brain following ozone exposure in rats maintained on coconut, fish and olive oil-rich diets. Int J Mol Sci. 2019;20:24. https://doi.org/10.3390/ijms20246303.

79. Shepherd DL, Hathaway QA, Nichols CE, Durr AJ, Pinti MV, Hughes KM, et al. Mitochondrial proteome disruption in the diabetic heart through targeted epigenetic regulation at the mitochondrial heat shock protein 70 (mtHsp70) nuclear locus. J Mol Cell Cardiol. 2018;119:104-15. https:// doi.org/10.1016/j.yjmcc.2018.04.016.

80. Nichols CE, Shepherd DL, Hathaway QA, Durr AJ, Thapa D, Abukabda A, et al. Reactive oxygen species damage drives cardiac and mitochondrial dysfunction following acute nano-titanium dioxide inhalation exposure. Nanotoxicology. 2018;12(1):32-48. https://doi.org/10.1080/17435390. 2017.1416202.
81. Taylor JP, Tse HM. The role of NADPH oxidases in infectious and inflammatory diseases. Redox Biol. 2021. https://doi.org/10.1016/j.redox.2021. 102159.

82. Panday A, Sahoo MK, Osorio D, Batra S. NADPH oxidases: an overview from structure to innate immunity-associated pathologies. Cell Mol Immunol. 2015;12(1):5-23. https://doi.org/10.1038/cmi.2014.89.

83. Lee IT, Yang CM. Role of NADPH oxidase/ROS in pro-inflammatory mediators-induced airway and pulmonary diseases. Biochem Pharmacol. 2012;84(5):581-90. https://doi.org/10.1016/j.bcp.2012.05.005.

84. Yao H, Edirisinghe I, Yang SR, Rajendrasozhan S, Kode A, Caito S, et al. Genetic ablation of NADPH oxidase enhances susceptibility to cigarette smoke-induced lung inflammation and emphysema in mice. Am J Pathol. 2008;172(5):1222-37. https://doi.org/10.2353/ajpath.2008.070765.

85. Yao H, Yang SR, Kode A, Rajendrasozhan S, Caito S, Adenuga D, et al. Redox regulation of lung inflammation: role of NADPH oxidase and NFkappaB signalling. Biochem Soc Trans. 2007;35(Pt 5):1151-5. https://doi. org/10.1042/BST0351151.

86. Diebold BA, Wilder SG, De Deken X, Meitzler JL, Doroshow JH, McCoy JW, et al. Guidelines for the detection of NADPH oxidases by immunoblot and RT-qPCR. Methods Mol Biol. 2019;1982:191-229. https://doi.org/10. 1007/978-1-4939-9424-3_12.

87. Kim MJ, Ryu JC, Kwon Y, Lee S, Bae YS, Yoon JH, et al. Dual oxidase 2 in lung epithelia is essential for hyperoxia-induced acute lung injury in mice. Antioxid Redox Signal. 2014;21(13):1803-18. https://doi.org/10. 1089/ars.2013.5677.

88. Fischer H. Mechanisms and function of DUOX in epithelia of the lung. Antioxid Redox Signal. 2009;11(10):2453-65. https://doi.org/10.1089/ARS. 2009.2558.

89. Cloonan SM, Kim K, Esteves P, Trian T, Barnes PJ. Mitochondrial dysfunction in lung ageing and disease. Eur Respir Rev. 2020;29:157. https://doi. org/10.1183/16000617.0165-2020.

90. Majumder N, Goldsmith WT, Kodali VK, Velayutham M, Friend SA, Khramtsov $W$, et al. Oxidant-induced epithelial alarmin pathway mediates lung inflammation and functional decline following ultrafine carbon and ozone inhalation co-exposure. Redox Biol. 2021;46: 102092. https://doi. org/10.1016/j.redox.2021.102092.

91. Rangarajan S, Bernard K, Thannickal VJ. Mitochondrial dysfunction in pulmonary fibrosis. Ann Am Thorac Soc. 2017;14 Supplement_5:S383-S8. https://doi.org/10.1513/AnnalsATS.201705-370AW.

92. Li F, Xu M, Wang M, Wang L, Wang $H$, Zhang $H$, et al. Roles of mitochondrial ROS and NLRP3 inflammasome in multiple ozone-induced lung inflammation and emphysema. Respir Res. 2018;19(1):230. https://doi. org/10.1186/s12931-018-0931-8.

93. Liu $X$, Chen Z. The pathophysiological role of mitochondrial oxidative stress in lung diseases. J Transl Med. 2017;15(1):207. https://doi.org/10 1186/s12967-017-1306-5.

94. Piantadosi CA, Suliman HB. Mitochondrial Dysfunction In Lung Pathogenesis. Annu Rev Physiol. 2017;79:495-515. https://doi.org/10.1146/annur ev-physiol-022516-034322.

95. Hoffmann RF, Jonker MR, Brandenburg SM, de Bruin HG, Ten Hacken NHT, van Oosterhout AJM, et al. Mitochondrial dysfunction increases proinflammatory cytokine production and impairs repair and corticosteroid responsiveness in lung epithelium. Sci Rep. 2019;9(1):15047. https://doi. org/10.1038/s41598-019-51517-x.

96. Lerner CA, Sundar IK, Rahman I. Mitochondrial redox system, dynamics, and dysfunction in lung inflammaging and COPD. Int J Biochem Cell Biol. 2016;81 Pt B:294-306. https://doi.org/10.1016/j.biocel.2016.07.026.

\section{Publisher's Note}

Springer Nature remains neutral with regard to jurisdictional claims in published maps and institutional affiliations. 